\title{
リウマチ患者のビタミン $\mathrm{B}_{1}$ 代謝に
}

\section{関する臨床的研究}

\author{
国立岩国病院整形外科医長 \\ 岡山大学医学部整形外科教室（指道 坚玉俊夫教授） \\ 専攻生 児玉玉寛
}

（昭和34年 6 月19日受稿）

\begin{tabular}{|c|c|}
\hline \multicolumn{2}{|c|}{ E } \\
\hline 第 I章 & 緒 \\
\hline 第正章 & $\mathrm{B}_{1}$ 定 量 法 \\
\hline 第卭章 & $\begin{array}{l}\text { 正常人, リウマチ患者, 腰痛症 } \\
\text { 患者の血中 } B_{1} \text { 値の比較 }\end{array}$ \\
\hline 第I章 & $\mathrm{B}_{1}$ 負荷臨床実騟 \\
\hline 第 $\nabla$ 章 & $\begin{array}{l}\text { リウマチドックに於ける } \mathbf{B}_{1} \text { 代 } \\
\text { 謝実騟 }\end{array}$ \\
\hline 第 1 節 & 马 $\mathrm{B}_{1}$ 投与と臨床症状の検討 \\
\hline 第 2 節 & 各種抗りウマチ剤と B、併用 \\
\hline
\end{tabular}

\section{第I章 緒訔}

昭和30年 6 月以降岡山大学医学部整形外科教室に於 て、児玉教授指过のもとに岡山リウマチ治療研究友の 会開設以来数多くのリウマチ患者に接するに，その大 多数において既応にビタミン B $_{1}$ (以下B 1 と略す) 剤 治療をうけており，然もその治療効果については患者 自身も不明のままに過しているものが多い。リウマチ の真の原因が未だ不明であり，一元論的には説明し難 い現状であるが、リウマチとB1に関しては数多くの 報告がある. 欧米では古くはStein'”或はFletcher ${ }^{2}$ 等は $\mathrm{B}_{1}$ 或は $\mathrm{B}_{1}$ を含む $\mathrm{B}$ 複合体を投与することにより リウマチ症状が好転したと述へ，反対に Freyberg ${ }^{8}$ ) はリウマチに対しB、は無奻であると報告している， 又Borson')はリウマチ患者28例中25例にB 欠乏を認 めたと述へ，その他にも $\mathrm{B}_{1}$ 欠乏説を唱える報告は多 いが，我が国でも齊藤のは本症の原因を $\mathbf{B}_{1}$ 欠亡 $+x$ であるとの考えのもとにB ${ }_{1}$ の大量療法を推賞せられ， 近森 ${ }^{62}$ ，佐山7) 等も臨床実験により $\mathrm{B}_{1}$ 久亡説を主張

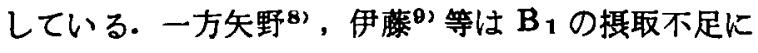
よる欠乏でなく，肝臓機能障害およひ内分泌障害に由 来する内因性のB 1 利用不全であると推論している.

私は幸い岡山リウマチ治療研究友の会招よひ31年 6
次

\begin{tabular}{|c|c|}
\hline & による血中 $B_{1}$ \\
\hline 第 3 節 & 血中 $\mathrm{B}_{1}$ 値と臨床症状との関係 \\
\hline 第 4 節 & 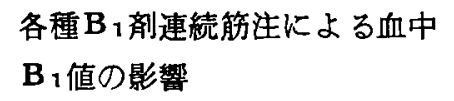 \\
\hline 第 5 節 & $\begin{array}{l}\text { アリナミン低量連続投与による } \\
\text { 血中 } \text { B }_{1} \text { 値の影響 }\end{array}$ \\
\hline 第VI章 & 忩括並びに考按 \\
\hline 第VII章 & 論 \\
\hline
\end{tabular}

月より発足したリウマチドックに於て数多くのリウマ チ患者に接することが出来, リウマチと $\mathrm{B}_{\mathbf{1}}$ 代謝との 関係を究明すへく臨床実験を試みた。

\section{第II章 $\mathbf{B}_{1}$ 定 量 法}

$\mathrm{B}_{\mathbf{1}}$ 定量法は，八木編：最新ビタミン定量法10) 以準 じ, 加水分解, パームチット吸・脱着, チオクローム 溃光法により測定を行つたが一部変更したので測定方 式を略述する.

血液は早朝空腹時 $11 \mathrm{ml} \sim 12 \mathrm{ml}$ を採血しこれをあ らかじめクエン酸ソーダ $20 \mathrm{mg}$ 入机た小三角コルベ ンに入机よく混和し凝固を防ぐ.

一方 2 本の $100 \mathrm{ml}$ のメスコルベンに蒸溜水約 $20 \mathrm{ml}$ を入れておき， $5 \mathrm{ml}$ のホールピベットにて正確に血 液 $5 \mathrm{ml}$ 採取してこれを入れ，充分溶血させる。遊離 型 $B_{1}$ 測定の際は蒸溜水を沸睠させ怙いてからこれに 血液を混じ，かくして浸出操作中に試料自身に含まれ るフオスファターゼの作用によつて，結合型 $\mathrm{B}_{1}$ の一 部が遊離型B1に变化する事を防いだ.

更にこれに $0.1 \mathrm{~N}$ 硫酸溶液 $45 \mathrm{ml}$ を加え混和後 $4 \mathrm{M}$ 酢酸ソーダ溶液 $3 \mathrm{ml}$ を加光 $\mathrm{pH}$ を4.5 補正し, 沸 腾浴20分を行い冷却後液量を $100 \mathrm{ml}$ に補正, $\mathrm{pH} 4.5$ とする. 
この一方はその盡遊離型 $\mathrm{B}_{1}$ の測定に使用するが， 総 $\mathrm{B}_{1}$ 測定の方は $5 \%$ タカジアスターゼ夜（あらかじ めパームチット層を通してB を加えて $45^{\circ} \mathrm{C} \sim 50^{\circ} \mathrm{C} て ゙ 1.5 \sim 2.0$ 時間作用させる, 冷 却後液量を $100 \mathrm{ml}$ に補正, 同時に $\mathrm{pH} 4.5$ とする. かくして得た浸出液は, それぞれ遠心沈澱(3000迴 転/ 1 分, 15分間) を行い更にその上清をガラス滤過器 で濾過して完全な上清を得る。この浸出液 ( $\mathrm{pH} \mathrm{4.5)}$ を正確に $50 \mathrm{ml}$ 取り，パームチットを入れた置換塔に しつかにそそき， 1 分間 $1 \mathrm{ml}$ (約 3 秘間に 1 滴の割 合）の速度で吸着させる.

正常尿中には結合型 $\mathrm{B}_{1}$ は排泄されないからそのま ま $\mathrm{pH}$ を補正して吸着させればよいのであるが，負荷 尿の場合は適当に稀釈したものの一定量（普通 $3 \sim 5$ $\mathrm{ml}$ ）に0.1N硫酸溶液 $15 \mathrm{ml} ， 4 \mathrm{M}$ 酢酸ソーダ $1 \mathrm{ml}$ 加え $\mathrm{pH} 4.5$ に補正後置換塔にそそき吸着させる.

かくして浸出液の吸着が終了すれは，更に $\mathrm{pH} 4.5$ の蒸溜水で置換塔内を洗い乍らガラス管壁に附着せる B 1 を残りなく吸着させる.

次に水洗であるが，これは沸騰蒸溜水で 数回(約 $60 \mathrm{ml}$, 速度は 1 秒間に 1 滴の割合) 行い脱着にうつ る.

脱着は沸腾 $25 \%$ 盃化カリ・程酸溶液 $25 \mathrm{ml}$ 置换塔 にそそき，出て来る脱着液を $25 \mathrm{ml}$ のメスシリンダー に受け (速度, 1 秒間 1 滴の割合), 冷却後 $25 \%$ 塩化 カリ・塩酸溶液にて正確に液量を $25 \mathrm{ml}$ に補正する。

酸化はブロムシアン法によつた．即ち脱着液をよく 混和後ホールピペットにて $5 \mathrm{ml}$ すつ採取、それぞれ 三本の共栓遠心沈澱管にとり, それぞれ主険, 添加,

盲桱とする。添加には $B_{1}$ 標準液の一定量 $(0.2 \sim 0.5$

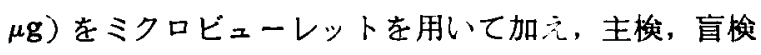
には pH 4.5 酢酸緩街液を同量加える.次いでプロム シアン溶液 $3 \mathrm{ml}$ 主検, 添加に加えよく混和後 $30 \%$ 苛性ソーダ溶液 $2 \mathrm{ml}$ を加えてよく混和する, 盲湌は 先に $30 \%$ 苛性ソーダ溶液 $2 \mathrm{ml}$ 加え混和後ブロムシ アン溶夜 $3 \mathrm{ml}$ を加えてよく混和する.

かくして後これら 3 本に再溜精製したブタノール10 $\mathrm{m} 1$ を加え強く振湦（100回）後, 精製無水芒硝 $2 \mathrm{~g}$ 在 加えて再ひ振燙（100回）の後, 遠心沈激（1000回転/ 1 分, 約 3 分間）在行い，上清のブタノールを螢光々 度計のキューベットにとり, 螢光々度計にてその螢光 度を測定する。（帛津光電分光光度計 Q B - 50型に螢 光度测定装置をつけて测定した).

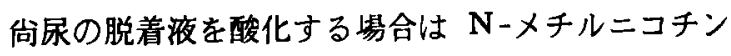
アミドの影響を防ぐため, ブロムシアン, 㱒性ソーダ
を加えた後, 10分間放置してブタノールを加えた。 かくして螢光々度計にて主検, 添加および盲検のメ 一ターの読みを $\mathrm{f}_{\mathrm{II}}, \mathrm{f}_{\mathrm{Z}}$, 及び $\mathrm{f}_{\mathrm{B}}$ とし, 試料の稀釈倍数 $\mathrm{V}$, 吸着させた浸出液量を $\mathrm{A}$, 脱着液量を $\mathrm{N}$, 酸化さ せた脱着液量を $\mathrm{D}$, 添加 $\mathrm{B}_{1}$ 量を $\mathrm{m}$ とすると主検中の $B_{1}$ 量は

$$
\mathrm{m} \times \frac{\mathrm{f}_{\mathrm{H}}-\mathrm{f}_{\mathrm{B}}}{\mathrm{f}_{z}-\mathrm{f}_{\mathrm{H}}}
$$

であるから, 試料中の $\mu \mathrm{g} / 100 \mathrm{~g}$ は次式によつて求め られる。

$$
x \mu \mathrm{g} / 100 \mathrm{~g}=\mathrm{m} \times \frac{\mathrm{f}_{\mathrm{H}}-\mathrm{f}_{\mathrm{B}}}{\mathrm{f}_{\mathrm{Z}}-\mathrm{f}_{\mathrm{H}}} \times \frac{\mathrm{N}}{\mathrm{D}} \times \frac{\mathrm{V}}{\mathrm{A}} \times 100 \mu \mathrm{g} / 100 \mathrm{~g}
$$

原法によれば $20 \mathrm{ml}$ 血液採血し，それそれ $10 \mathrm{ml}$ 在 用いて測定する様になつているが，リウマチ性患者は 貝血在伴い，汃肘静脈よりの採血がしばしば困難で あるため，同一血液にて $10 \mathrm{ml}$ 及び $5 \mathrm{ml}$ を用いて測 定してみた結果，両者の測定值に差なきことを確めた 上で $5 \mathrm{ml}$ 使用法を採用した。

台 $\mathrm{B}_{1}$ 定量手技は熟練を要するため，長時日を費い やして充分習等した後に本実䮖に入つた. 又実験はす ペて同日終了を目的として計画した。

\section{第临正常人, リゥマチ患者, 腰 痛症患者の血中B、值の比較}

健康正常人に於ける血中 $\mathrm{B}_{1}$ 量及び 1 日尿中 $\mathrm{B}_{1}$ 排泄 量については: 表 $1 ， 2$ 山の如く諸家の報告がある. 日本人健康正常人の血种総 $\mathrm{B}_{1}$ 量については,ビタミン B研究特別委員会では $10 \pm 3 \mu \mathrm{g} / \mathrm{dl}^{12}$ )とされ，その 外諸家の報告があるが大体平均値は $6 \sim 8 \mu \mathrm{g} / \mathrm{d} 1$ と考 えられているようである。

正常人 (13例), リウマチ患者 (18例), 腰痡症患者 (9 例) につき血中B1值を测定し比較検討してみた. 測定にあたつては 1 週間の $\mathrm{B}_{1}$ 投与休止期間を置ぎ， 早朝空腹時に採血測定した。

表 3 ）の如くリウマチ患者血中 $B_{1}$ 値は13例の平均 值で括離型 $\mathrm{B}_{1} 1.8 \mu \mathrm{g} / \mathrm{dl}$, 結合型 $\mathrm{B}_{1} 2.1 \mu \mathrm{g} / \mathrm{dl}$, 総 $\mathrm{B}_{1} 3.9 \mu \mathrm{g} / \mathrm{dl}$ となり, 腰痛症患者では症例 9 例の平 均值は表 4）の如く遊離型 $\mathrm{B}_{1} 1.5 \mu \mathrm{g} / \mathrm{dl}$, 結合型 $\mathrm{B}_{1}$ $3.6 \mu \mathrm{g} / \mathrm{dl}$, 総 $\mathrm{B}_{1} 5.1 \mu \mathrm{g} / \mathrm{dl}$, となり, 更に健康人て は表 5 の如く遊離型 $\mathrm{B}_{1} 0.9 \mu \mathrm{g} / \mathrm{dl}$ ，結合型 $\mathrm{B}_{\mathbf{1}} 5.2 \mu \mathrm{g} /$ $\mathrm{dl}$, 総 $\mathrm{B}, 6.1 \mu \mathrm{g} / \mathrm{dl}$ となり, これを比較検討するに 図 1) の如く関節りウマチ患者では 総B 1 量に於て健 康人に比し明らかに低値を示し，これとは逆に茞くわ ずかではあるが遊離型 B、に堌量が見られる，従つて 結合型B 1 たる Cocarboxylaseは 明らかに低値を示 している. 又上記 3 者の附燐率を見るに関節リウマチ 
表 1 血 中 $\mathrm{B}_{1}$ 量

\begin{tabular}{|c|c|}
\hline 告 & 血中 $B_{1}$ 量 $(\mu \mathrm{g} / \mathrm{dl})$ \\
\hline Schneider and Burger & $3.8 \sim 10$ (平均 6.4 ) \\
\hline \multirow{2}{*}{$\begin{array}{l}\text { Widenbauer et al. } \\
\text { Ritsert }\end{array}$} & $2 \sim 11 \quad($ \\
\hline & $3 \sim 15 \quad(7.9 \pm 3.9)$ \\
\hline Hennessy and Cerecedo & $9 \sim 12$ \\
\hline Magyar & $1 \sim 15 \quad(7.6)$ \\
\hline Molner and Morani & $(19.5 \pm 3.5)$ \\
\hline Benson et al. & $4.8 \sim 12.3(7.8 \pm 1.3)$ \\
\hline Williams et al. & $6 \sim 9$ \\
\hline ビタミンB研究特別委員会 & $(10 \pm 3)$ \\
\hline 須沢 & $(8.5 \pm 1.7)$ \\
\hline （井 & 上） \\
\hline
\end{tabular}

表 2 尿 中 $\mathrm{B}_{1}$ 量

\begin{tabular}{l|c}
\hline \hline \multicolumn{1}{c|}{ 報 告 者 } & $\begin{array}{c}\text { 健康者に於ける1 日尿中 } \\
\mathrm{B}_{1} \text { 量 }(\mu \mathrm{g})\end{array}$ \\
\hline Golliffe et al. & 300 \\
Wang and Harris & $150 \sim 240$ \\
Melnick & $890 \sim$ \% $60 \sim$ \\
Hills & $50 \sim 170$ \\
Ritsert & $110 \sim 520$ \\
Borson & $100 \sim 300$ \\
Benson & 150 \\
岩 崎 & $190 \pm 28$ \\
杉 浦 & 179 \\
島 䓟 & $233 \sim 710$ \\
須 沢 & $356 \sim 162$
\end{tabular}

（井上）

表 3

リウマチ患者 血中 $\mathbf{B}_{\mathbf{1}}$ 值

\begin{tabular}{|c|c|c|c|c|c|c|c|c|c|c|c|c|c|c|}
\hline \multirow{2}{*}{ 症例 } & \multirow{2}{*}{ 氏 } & \multirow{2}{*}{ 名 } & \multirow{2}{*}{$\begin{array}{l}\text { 年 } \\
\text { 令 }\end{array}$} & \multirow{2}{*}{$\begin{array}{l}\text { 性 } \\
\text { 別 }\end{array}$} & \multirow{2}{*}{ Stage } & \multirow{2}{*}{ Class } & \multicolumn{3}{|c|}{ 血中 $B_{1}$ 値 $(\mu \mathrm{g} / \mathrm{dl})$} & \multirow{2}{*}{\begin{tabular}{|l|} 
赤血球 \\
数(万)
\end{tabular}} & \multirow{2}{*}{$\begin{array}{c}\mathrm{Hb} \\
(\%)\end{array}$} & \multicolumn{2}{|c|}{ 赤 沈 值 } & \multirow{2}{*}{ 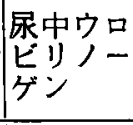 } \\
\hline & & & & & & & F & $\mathrm{T}$ & $\mathbf{E}$ & & & 1 時間 & 2 時間 & \\
\hline 1 & 古 & 0 & 50 & q & 3 & 2 & 1.1 & 3.4 & 2.4 & 312 & 68 & 55 & 94 & + \\
\hline 2 & 藤 & 0 & 29 & $\delta$ & 1 & 1 & 0 & 4.4 & 4.4 & 438 & 95 & 6 & 16 & $(+)$ \\
\hline 3 & $\equiv$ & 0 & 34 & ㅇ & 1 & 1 & 0 & 4.9 & 4.9 & 410 & 82 & 75 & 115 & $(+)$ \\
\hline 4 & 間 & 0 & 66 & 9 & 2 & 2 & 0 & 5.5 & 5.5 & 372 & 65 & 35 & 60 & + \\
\hline 5 & 尾 & 0 & 21 & ㅇ & 3 & 3 & 0.6 & 5.9 & 5.3 & 288 & 30 & 26 & 63 & $(+)$ \\
\hline 6 & 占 & 0 & 52 & $\delta$ & 1 & 1 & 0.1 & 4.9 & 4.8 & & & 9 & 23 & $(+)$ \\
\hline 7 & 片 & 0 & 42 & q & 2 & 2 & 1.5 & 3.9 & 2.4 & 385 & 79 & 107 & 122 & $(+)$ \\
\hline 8 & 伊 & 0 & 40 & $\delta$ & 2 & 2 & 2.3 & 3.8 & 1.5 & 350 & 70 & 29 & 50 & $(+)$ \\
\hline 9 & 神 & 0 & 28 & $\hat{\delta}$ & 3 & 3 & 0.2 & 3.4 & 3.2 & 485 & 79 & 47 & 89 & $(+)$ \\
\hline 10 & 横 & 0 & 21 & q & 2 & 2 & 0.9 & 2.8 & 1.9 & 354 & 40 & 100 & 117 & + \\
\hline 11 & 本 & 0 & 12 & $\delta$ & 1 & 2 & 2.1 & 5.1 & 3.0 & 470 & 80 & 16 & 41 & $(+)$ \\
\hline 12 & 作: & 0 & 49 & $\delta$ & 1 & 1 & 2.1 & 6.6 & 4.5 & & & 8 & 18 & \\
\hline 13 & 遠 & 0 & 43 & 우 & 2 & 2 & 2.0 & 4.9 & 2.9 & & & 118 & 136 & \\
\hline 14 & 虫 & 0 & 41 & 9 & 3 & 2 & 2.1 & 2.6 & 0.5 & 368 & 56 & 146 & 150 & $(+)$ \\
\hline 15 & 平 & 0 & 28 & ㅇ & 1 & 2 & 1.3 & 2.3 & 1.0 & 250 & 58 & 62 & 103 & $(+)$ \\
\hline 16 & & & 32 & $\delta$ & 1 & 2 & 0.6 & 2.0 & 1.4 & & & 1 & 3 & \\
\hline 17 & 岡 & 0 & 21 & q & 1 & 1 & 1.2 & 5.1 & 3.9 & 330 & 73 & 7 & & $(+)$ \\
\hline 18 & 芦 & 0 & 31 & ㅇ & 1 & 1 & 1.5 & 5.1 & 3.6 & 395 & 65 & 5 & 15 & $(+)$ \\
\hline & & & 均 & & & & 1.8 & 3.9 & 2.1 & & & & & \\
\hline
\end{tabular}

註 $\mathbf{F}$ : 遊離型 $\mathbf{B}_{1} \quad \mathbf{T}$ : 総 $\mathbf{B}_{1} \quad \mathrm{E}$ : 結合型 $\mathbf{B}_{1}$ 
5010

児王

表 4 腰痡症患者血中 B 1 值

\begin{tabular}{|c|c|c|c|c|c|c|c|c|c|}
\hline \multirow{2}{*}{$\begin{array}{l}\text { 症 } \\
\text { 例 }\end{array}$} & \multirow{2}{*}{ 氏 } & \multirow{2}{*}{ 名 } & \multirow{2}{*}{$\begin{array}{l}\text { 年 } \\
\text { 令 }\end{array}$} & \multirow{2}{*}{$\begin{array}{l}\text { 性 } \\
\text { 別 }\end{array}$} & \multicolumn{3}{|c|}{$\begin{array}{c}\text { 血中 } \mathrm{B}_{1} \text { 值 } \\
(\mu \mathrm{g} / \mathrm{dl})\end{array}$} & \multicolumn{2}{|c|}{ 血沈値 } \\
\hline & & & & & $\begin{array}{l}\text { 遊離 } \\
\text { 型 }\end{array}$ & \begin{tabular}{l|} 
総 \\
$\mathbf{B}_{1}$
\end{tabular} & $\begin{array}{l}\text { 結合 } \\
\text { 型 }\end{array}$ & $\begin{array}{c}1 \\
\text { 時間 }\end{array}$ & $\begin{array}{c}2 \\
2 \\
\text { 特間 }\end{array}$ \\
\hline 1 & 北 & 0 & 38 & 우 & 0.4 & 3.6 & 3.2 & 12 & 23 \\
\hline 2 & 平 & 0 & 46 & 우 & 0.6 & 4.6 & 4.6 & 3 & 8 \\
\hline 3 & 小 & 0 & 52 & $\delta$ & 1.6 & 5.0 & 3.4 & 11 & 23 \\
\hline 4 & 花 & 0 & 23 & $\delta$ & 0.5 & 4.7 & 4.2 & & \\
\hline 5 & 高 & 0 & 23 & $\delta$ & 1.3 & 5.4 & 4.1 & & \\
\hline 6 & 友 & 0 & 32 & $\delta$ & 0.1 & 2.3 & 2.1 & 5 & 17 \\
\hline 7 & 田 & 0 & 36 & $\delta$ & 1.3 & 4.1 & 2.8 & 25 & 59 \\
\hline 8 & 石 & 0 & 49 & $\delta$ & 1.6 & 5.7 & 4.1 & 8 & 21 \\
\hline 9 & 高 & 0 & 35 & $\delta$ & 1.5 & 5.1 & 4.0 & 3 & 10 \\
\hline & & 坷 & 値 & & 1.5 & 5.1 & 3.6 & & \\
\hline
\end{tabular}

表 5 健康者血中 $B_{1}$ 値

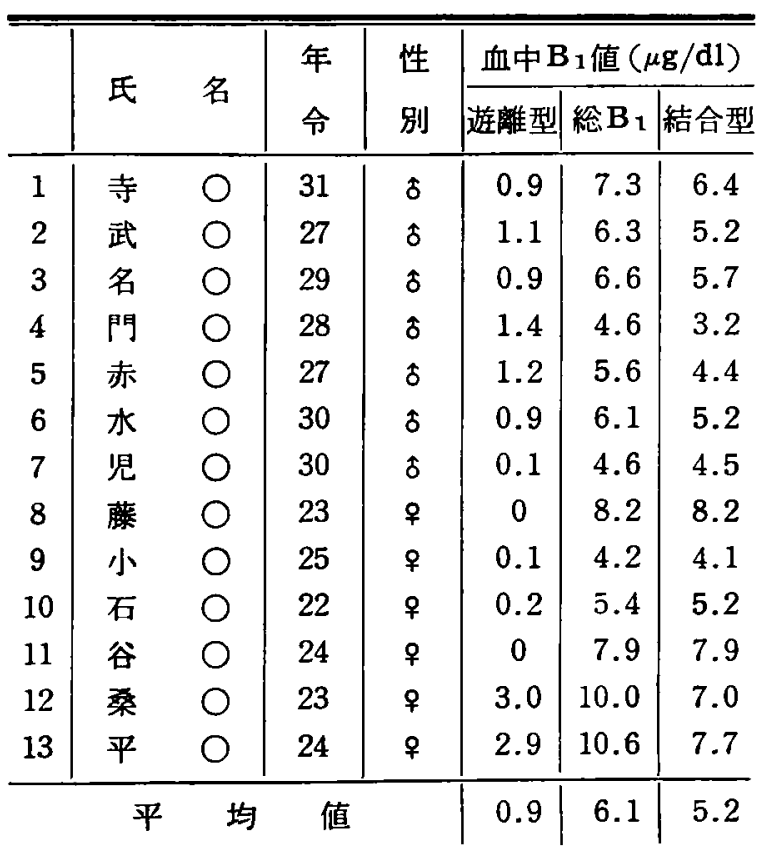

図1 関節リウマチ患者（18例）の夫々の血中 腰痛症患者 (9 例) $\mathrm{B}_{1}$ 値 (平均 正常人 (13例) 值) 比较

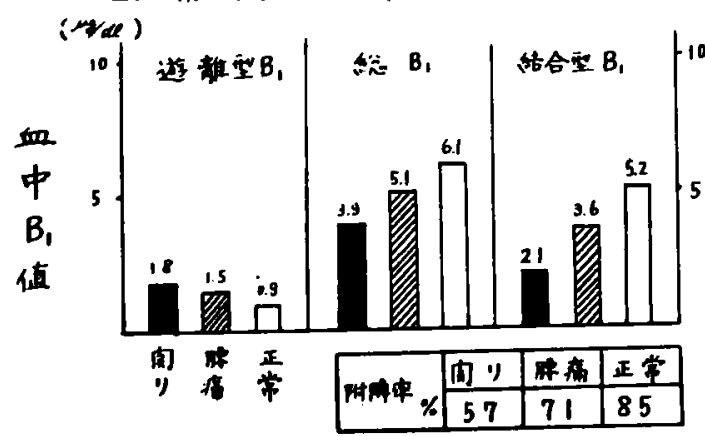

賽

患者のそれは54\%であり，健康人の $85 \%$ に比し著しく 低値を示している，份腰痛症患者では，両者のほぼ中 間値を示していた。

[小括] 従来関節リウマチ患者血中 $\mathrm{B}_{1}$ 値の低下に ついては諸家の認めるところであり，最近でも伊藤の) はリウマチ患者のB 1 代謝に関する臨床的実験に於て， 血中総 $\mathrm{B}_{1}$ 量の低値を認めている．私の臨床実験に於 ても明らかに総 $\mathrm{B}_{1}$ 量の低値を示すと共に，血中 $\mathrm{B}_{1}$ の 附燐率の低下即ち Cocarboxylase の低值加認められ た.この事実は関節リウマチ患者の大多数に於て肝臓 機能障害及ひ潜在性障害が認めら㧈る事と一致してい る.

又表 6）の如く関節りウマチ患者に於ける Stage, Class (Steinbrocker の分類による) ${ }^{+2)}$ と赤沈, 血 中 $\mathrm{B}_{1}$ 值 及び その附燐率を比較してみるに, Stage, Class 共に軽症例に於汀る 6 例では，赤沈の㠵進もあ まり見られず，附燐率も健康人のそれにほぼ一致して いるが症状の進行, 機能障害の進むにつれて赤沈値の 光進が見られ，血中 $B_{1}$ 値の低下と共に附燐率も減少 の傾向にある様に思われる。

表 6 関節リウマチ患者に於ける Stage, Classに よる分類及び赤沈値と血中 $\mathrm{B}_{1}$ 值との関係

\begin{tabular}{|c|c|c|c|c|c|c|c|}
\hline $\begin{array}{l}\text { 症 } \\
\text { 峢 }\end{array}$ & Stage & Class & $\left(\begin{array}{c}\text { 赤沈値 } \\
\text { 時間 }\end{array}\right)$ & $\begin{array}{c}\text { 遊離型 } \\
\mathrm{B}_{1} \\
(\mu \mathrm{g} / \mathrm{dl})\end{array}$ & $\begin{array}{c}\text { 総 } \mathrm{B}_{1} \\
(\mu \mathrm{g} / \mathrm{dl})\end{array}$ & $\begin{array}{c}\text { 結合型 } \\
\mathrm{B}_{\mathrm{I}} \\
(\mu \mathrm{g} / \mathrm{dl})\end{array}$ & $\begin{array}{l}\text { 附煒 } \\
(\%) \\
(\%)\end{array}$ \\
\hline 6 & 1 & 1 & 18 & 0.8 & 5.2 & 4.4 & 85 \\
\hline 3 & 1 & 2 & 26 & 1.3 & 3.1 & 1.8 & 58 \\
\hline 5 & 2 & 2 & 90 & 1.3 & 4.2 & 2.9 & 69 \\
\hline 2 & 3 & 2 & 101 & 1.6 & 3.0 & 1.4 & 47 \\
\hline 2 & 3 & 3 & 37 & 0.4 & 4.7 & 4.3 & 91 \\
\hline
\end{tabular}

詰 1) 数値はそれそれの平均値を示す

2) 分類は Steinbrocker42'による.

\section{第 IV 章 $\quad \mathbf{B}_{1}$ 負荷臨床実験}

従来 $\mathrm{B}_{1}$ 欠之症に対する $\mathrm{B}_{1}$ 負荷試験か種々行わ㞦一 いるが，ただ 1 個の血中或は尿中 $\mathrm{B}_{1}$ 量の洌定のみで は $B_{1}$ 欠之の指標となり得ないことが多い．この意味 で $\mathrm{B}_{1}$ の負荷試験が行われているか，動物が $\mathrm{B}_{1}$ 欠乏に

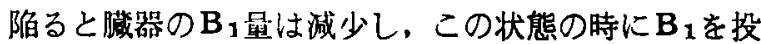
与すると，初期には $\mathrm{B}_{1}$ 性筬器内に詝藏されて尿中に は排泄されないが，聍藏量が充分となると急に尿中に 排泄される様になる。

Hills ${ }^{13}$ は $B_{1} 1 \mathrm{mg}$ の経口投与を行い3 時間の尿 中 $B_{1}$ 排洲量を測定して，健康人では26 110(平均65) 
$\mu \mathrm{g}$ が排泄されたが，B1久例では殆んど增加しない と述へ, Melnick 14)等は B1 5 mgを释口投与し, 24 時間尿中に健康者では10〜20\%が排泄され，久乏症て は10\%以下であると報告している，又，川崎，中川16゙ 等の経口投与による尿中 $\mathrm{B}_{1}$ 排泄量により，その欠之 症を推定する報告もある.

しかし，経口投与はその吸収が問面となるので， Magyar ${ }^{16)}$ は $B_{1} 20 \mathrm{mg}$ 静脈内負荷を行い，24時間尿 中の $B_{1}$ 排泄量を測定して，健康者では18～56\%であ り，18\%以下を久乏としている。一方 Westenbrink' Goudsmit 17 は B $_{1}$ 負荷後における尿中排泄量には健 康例と欠乏例との間に有意の差はないとし, 又岩松(8) も初期脚気患者を対象として，B $11 \mathrm{mg}$ 皮下注射によ る負荷試験を行い, 3 時間尿中 $\mathrm{B}_{1}$ 排泄量を観察してそ の大多数例に減少を認めているが, 又少数例ではある が明らかに臨床症状を呈している患者にもかかからず 尿中 $\mathrm{B}_{1}$ の正常なることを報告している。井上10'は $B_{1}$ 利用能の低下という镜点より生体内 $B_{1}$ 代謝状況判 定法として， $B_{1} 20 \mathrm{mg}$ 皮下注射による負荷試験を行 い，㭘查前及び負荷後 30 分及び 1 時間の血中濃度, 更 K 3 時間尿中に排泄される $\mathrm{B}_{1}$ 量をもつて判定の基準 とした．即ち健康正常人では血中総 $\mathrm{B}_{1}$ 星が 30 分で最 高となり結合型 $\mathrm{B}_{1}$ にはあまり変化が見られない（図 2 参照 井上より) 病的形熊に 2 型あつて, その第 $I$ 型は尿中 $\mathrm{B}_{1}$ 排泄が少く, 血中 $\mathrm{B}_{1}$ 值の最高値も低いが 結合型が增加する型て，これは体内に於ける $\mathrm{B}_{1}$ 欠之

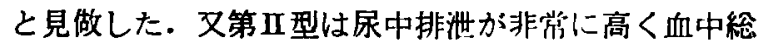
$\mathrm{B}_{1}$ 值の变動曲線も高いが結合型 $\mathrm{B}_{1}$ に著变の見られな いもので，これは体内に於ける $\mathrm{B}_{1}$ 利用能低下と見做 し, 肝疾患, 神経系疾患, 内分泌系疾患かこ虬に属す るとした. 又九大温研伊藤"゙リウマ忠者のビタミ
ン $\mathrm{B}_{1}$ 代謝に関する臨床的研究の中で，健康人，関節リ ウマチ患者にこの負荷試験を行い,リウマチ患者では 第正型に類似して B $_{1}$ 利用能の低下を推定している.

図 2 脚気型 ( I 型) 及び肝蔵疾患（II型） に対する $\mathrm{B}_{1} 20 \mathrm{mg}$ 負荷試験（井上）

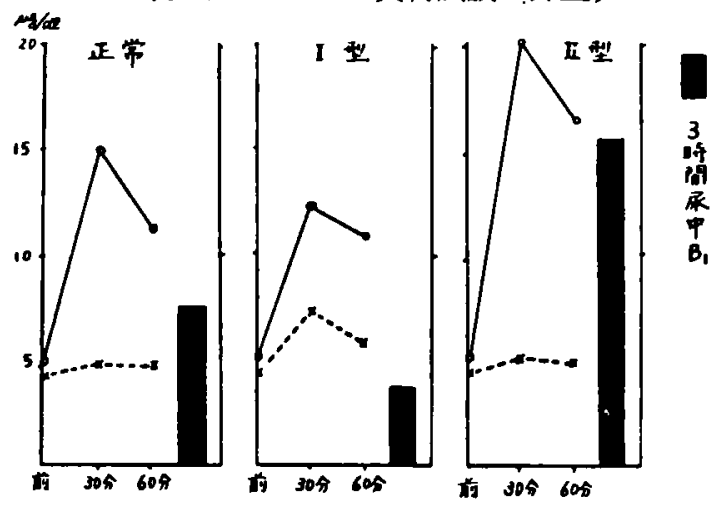

私も 3 例の少数ではあるが関節リウマチ患者及びそ の対象群として健康者 3 例をえ 5 び $\mathrm{B}_{1} 20 \mathrm{mg}$ 皮下注 射による負荷試駼を試みた。

表 7,8 に示す如く，健康正常人では 3 例の平均值が， 30 分で検查前に比し血中総 $B_{1}$ 值は $9.7 \mu \mathrm{g} / \mathrm{d}$ 增加して いるのに対し，関節りウマチ患者のそれは $18.0 \mu \mathrm{g} / \mathrm{d} 1$ と著しく高値を示している，又60分では健康者 3.7 $\mu \mathrm{g} / \mathrm{dl}$ ，関節リウマチ患者 $13.6 \mu \mathrm{g} / \mathrm{dl}$ の增加を見てい る. 又衤中排泄 $\mathrm{B}_{1}$ 量では 3 時間尿で健康者 $7949 \mu \mathrm{g}$ 投与量の䄪 39.7\%であるにたいし,リウマチ患者では $12934 \mu \mathrm{g}$ ，即ち投与量の約 $64 \%$ の排泄を見ている.一方 結合型 $\mathrm{B}_{1}$ 値は大した著変なく，健康者30分で $1.2 \mu \mathrm{g} /$ $\mathrm{dl}, 60$ 分で $0.6 \mu \mathrm{g} / \mathrm{dl}$ の增加に対して,関節リウマチ患 者では30分 $2.4 \mu \mathrm{g} / \mathrm{dl}, 60$ 分 $2.0 \mu \mathrm{g} / \mathrm{dl}$ の增加を見てい るのみである.

表 7

$\mathrm{B}_{1} 20 \mathrm{mg}$ 筋注負荷試験（関節リウマチ患者）

\begin{tabular}{|c|c|c|c|c|c|c|c|c|c|c|c|c|}
\hline \multirow{3}{*}{ 症 } & \multirow{3}{*}{ 氏 } & \multirow{3}{*}{ 名 } & \multicolumn{9}{|c|}{ 血 中 $\mathrm{B}_{1}$ 値 $(\mu \mathrm{g} / \mathrm{d} \mathrm{l})$} & \multirow{3}{*}{ 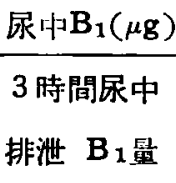 } \\
\hline & & & \multirow{2}{*}{$\frac{\text { 迶 }}{\text { 前 }}$} & 離 型 & $\mathbf{B}_{1}$ & \multicolumn{3}{|c|}{ 総 $\mathbf{B}_{1}$} & 結 & \multicolumn{2}{|c|}{ 合 型 $\mathbf{B}_{\mathbf{1}}$} & \\
\hline & & & & 30 分 & 1 時問 & 前 & 30 分 & 1 時間 & 前 & 30 分 & 1 時間 & \\
\hline 1 & 横 & 0 & 0.9 & 16.8 & 13.0 & 2.8 & 21.3 & 17.4 & 1.9 & 4.5 & 4.1 & 13852 \\
\hline 2 & 村 & 0 & 1.5 & 13.2 & 11.4 & 3.9 & 18.4 & 15.5 & 2.4 & 5.2 & 5.2 & 14091 \\
\hline 3 & 金 & 0 & 0.2 & 18.6 & 12.3 & 3.4 & 24.6 & 18.1 & 3.2 & 6.0 & 5.8 & 10961 \\
\hline & 均 & 值 & 0.6 & 16.2 & 12.2 & 3.4 & 21.4 & 17.0 & 2.8 & 5.2 & 4.8 & 12934 \\
\hline & 均 & 增 & 量 & $\begin{array}{l}(+) \\
15.6\end{array}$ & $\begin{array}{l}(+) \\
11.6\end{array}$ & & $\begin{array}{l}(+) \\
18.0\end{array}$ & $\begin{array}{l}(+) \\
13.6\end{array}$ & & $\begin{array}{l}(+) \\
2.4\end{array}$ & $\begin{array}{l}(+) \\
2.0\end{array}$ & $\begin{array}{l}\text { 角荷量の } \\
\text { 約 } 64 \%\end{array}$ \\
\hline
\end{tabular}


B1 $20 \mathrm{mg}$ 筋注負荷負荷試駺（正常健康人）

\begin{tabular}{|c|c|c|c|c|c|c|c|c|c|c|c|c|}
\hline & \multirow{3}{*}{ 氏 } & \multirow{3}{*}{ 名 } & \multicolumn{9}{|c|}{ 血 中 $B_{1}$ 値 $(\mu \mathrm{g} / \mathrm{dl})$} & \multirow{3}{*}{$\begin{array}{l}\text { 尿中 } \mathrm{B}_{1}(\mu \mathrm{g}) \\
3 \text { 時間尿中 } \\
\text { 排泄 } \mathrm{B}_{1} \text { 量 }\end{array}$} \\
\hline & & & 遊 & \multicolumn{2}{|c|}{ 離 型 $\mathbf{B}_{1}$} & \multicolumn{3}{|c|}{ 総 $\mathbf{B}_{1}$} & 結 & \multicolumn{2}{|c|}{ 合 型 $\mathbf{B}_{1}$} & \\
\hline & & & 前 & 30 分 & 60 分 & 前 & 30 分 & 60 分 & 前 & 30 分 & 60 分 & \\
\hline 1 & 0 & 田 & 1.4 & 9.9 & 4.7 & 4.6 & 14.5 & 8.5 & 3.2 & 4.6 & 3.8 & 7560 \\
\hline 2 & 0 & 玉 & 0.1 & 11.7 & 5.5 & 4.6 & 18.0 & 10.5 & 4.5 & 5.3 & 5.0 & 8320 \\
\hline 3 & $\mathrm{O}$ & 野 & 0.9 & 6.0 & 1.7 & 6.1 & 12.0 & 7.6 & 5.2 & 6.0 & 5.9 & 7965 \\
\hline & 平 均 & 値 & 0.8 & 9.3 & 4.0 & 5.1 & 14.8 & 8.9 & 4.3 & 5.5 & 4.9 & 7948 \\
\hline & 平 均 & 增 & 量 & $\begin{array}{r}(+) \\
8.5\end{array}$ & $\begin{array}{c}(+) \\
3.2\end{array}$ & & $\stackrel{(+)}{9.7}$ & $\begin{array}{c}(+) \\
3.7\end{array}$ & & $\begin{array}{c}(+) \\
1.2\end{array}$ & $\begin{array}{c}(+) \\
0.6\end{array}$ & $\begin{array}{l}\text { 奂荷量の } \\
\text { 約 } 39.7 \% \%\end{array}$ \\
\hline
\end{tabular}

[小括]これを図示すれば（図 3)，関節リウマチ患 者の $\mathrm{B}_{1} 20 \mathrm{mg}$ 皮下注射負荷試験の結果は, 総 $\mathrm{B}_{1}$ の高 度の上㫒は見られるが, 結合型 $\mathbf{B}_{1}$ に著変なく, 又尿 中排泄が健康人に比して増量していることより, 井上 のいわゆる第开型に類似する, 即ち体内に於ける $\mathrm{B}_{1}$ 利用能の低下と見做し得る如き結果を得た。

図3

$B_{1} 20 \mathrm{mg}$ 筇注負荷試験

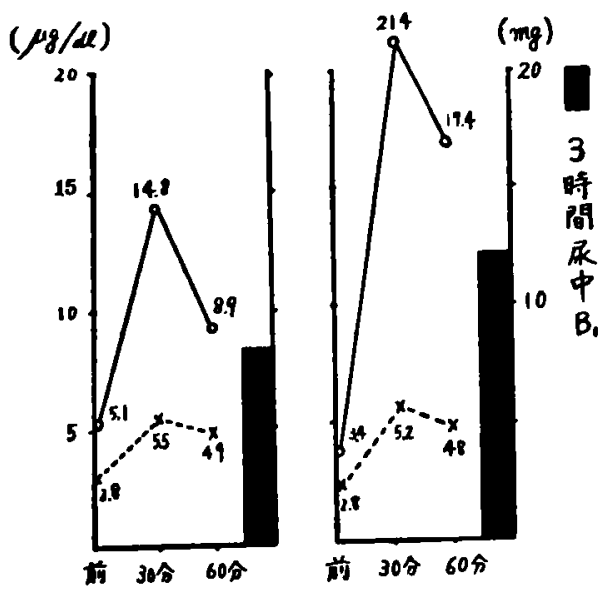

第V章 リウマチドックに於ける B 1 代謝実験

\section{第1 慨 B 1 投与と留床症状の湌㣙}

私達は31年 6 月以来, リウマチ患者の 1 ケ月入院を 行い，その間に於てリウマチ患者に対する今後の適当 なる治㞠方針確立の目的で, 諸種抗りウマチ片による 全身療法及ひ局所療法, 更にレハビリテーション等学 目的として居り，すで児玉(俊) $5^{20}$ によつてりウ マチドックの紹介が行われて来た. 即ち第 $1 ， 2 ， 3$ ，
4 週とそれそれ副腎皮質ホルモンの最低維持量の決 定，更にアスピリン，ブタゾリジン等の使用及びステ ロイドホルモンとの併用, 局所憭法, レハビリテーシ ョンを目的として行つている.

Thiol 型 $\mathrm{B}_{1}$ の誘導体である Thiamine propyl disulfide (アリナミン，武田）はその化学構造及び薬 理作用も解明され，あらゆる点でB、に優ることはす ヘてて報告の一致するとこうであり，更にリウマチに

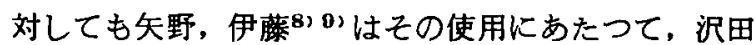
氏尿反応の陽性率が高いことを認めている。

私はこの見地より,リウマチドック全期間中に亘り， アリナミン $20 \mathrm{mg}$ を経口投与してみた.リウマチド ックの経験については、さきに報告されているが，そ の 1 症例を示してみる（図，4）.

即ちこの症例では，第 1 週メドロール，第 2 週ブレ ドニソロン，第 3 週ブタソリジン，更に第 4 週ブレド ニソロン及びブタソリジンの併用とを行つているが, この症例の第1週末に於ける如く,アリナミンの大量投 与を行い,血中 $B_{1}$ 值は内服後1時間にて総 $B_{1}$ 値 $9.8 \mu \mathrm{g}$ $/ \mathrm{dl}$ 結合型 $\mathrm{B}_{1}$ も $1.6 \mu \mathrm{g} / \mathrm{dl}$ より $2.8 \mu \mathrm{g} / \mathrm{d} 1$ と增加せる にも関わらず，メドロール投与を中止すれば一時的に 疼痛曲線の上年を来し，プレドニソロン投与開始で再 び下降している。

[小括] 私は多数例に於て，かかる $\mathrm{B}_{1}$ 血中濃度上 年にも関わらず，抗りウマチ刻投与中止によつて著明 な疼痛曲線の上年を見た・かかる観点より,リウマチ患 者には， $\mathrm{B}_{1}$ 利用能低下による血中 $\mathrm{B}_{1}$ 值の娍少は認め られたが，臨床症状観察の結果より， $\mathbf{B}_{1}$ 血中濃度上 界によるリウマチの鎮痛効果は少ない様に思われた。

\section{第2節 各程抗リウマチ玮とB 1 併用による 血中日 1 湿度の影表}


図 4

リウマチドックに於ける 1 症例

三○里 $\bigcirc$ 女 22 才 $2-2-2$

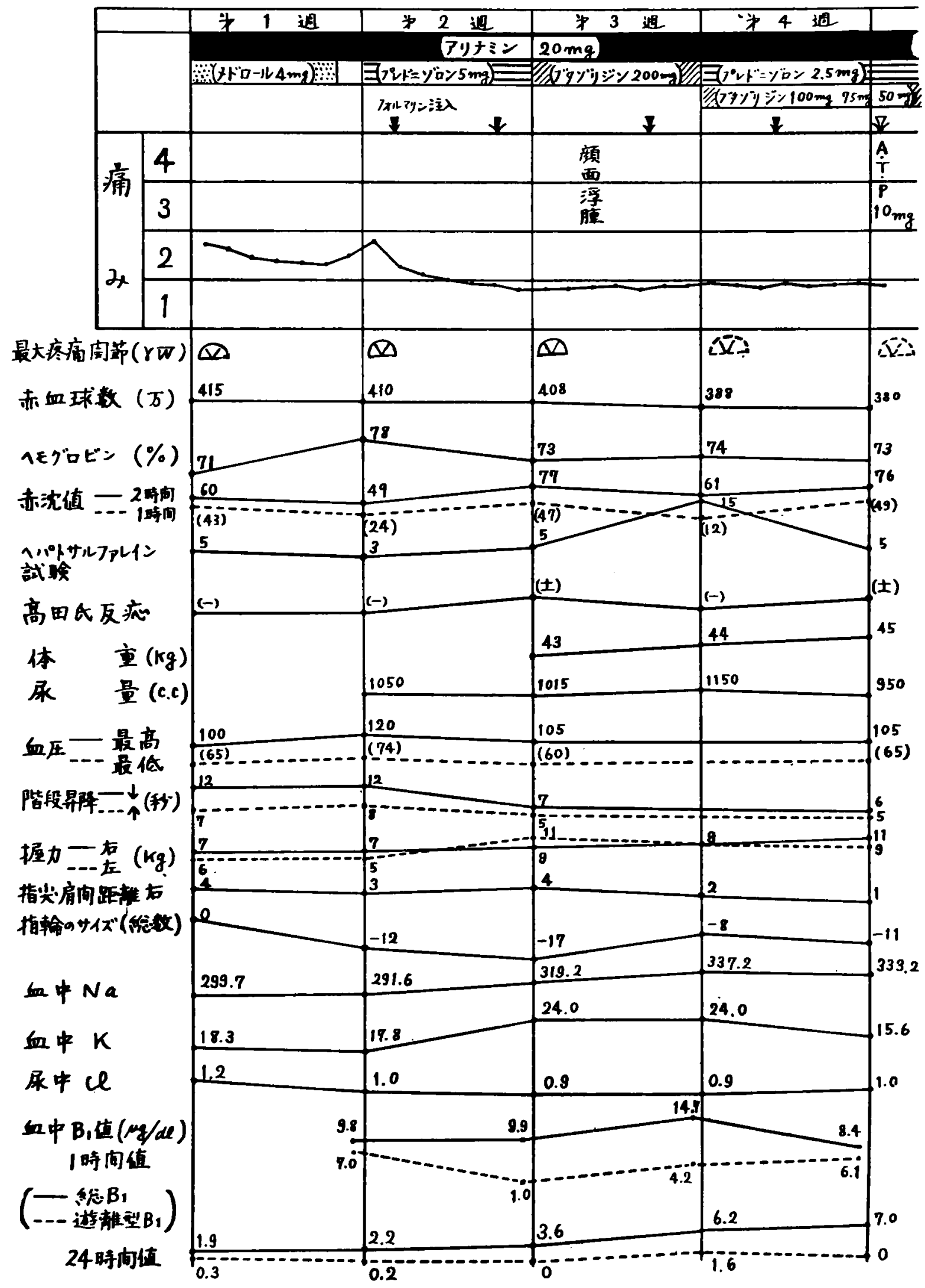


従来 $\mathrm{B}_{1}$ と副腎皮質ホルモンとの関係については多 くの報告があり, 井上21222２3（肝障害時， $\mathrm{B}_{1}$ の代 りにCocarboxylaseを用いると $\mathrm{B}_{1}$ 利用を高め, $\mathrm{B}_{1}$ と 副堅皮質ホルモンの併用は血中 $\mathbf{B}_{1}$ 値を上界させかつ 尿中B 1 排泄減少させるが, Desoxycorticosteron Acetate (DOCA) にはこの作用がないといつている， 又峰下24)も同様意見を述へている，小黒の゙はACTH, Cortison, Interenin 及ひ TTG と $\mathrm{B}_{1}$ との関係は， $B_{1}$ 負荷による尿中洪水現象の抑制について，ACTH がその作用最も強く，Interenin,TTGがこれにつぎ Cortison は軽度であるとい: こ, この機序に関して ACTH は副腎皮質ホルモンを介して $\mathrm{B}_{1}$ の附燐作用を 高めるためであると考えている．又高橋26) はDOCA と $\mathrm{B}_{1}$ の併用が Cocarboxylase 合成機能に役立つと いつている. その外 $\mathrm{B}_{1}$ とクルクロン酸との関係につ いて，小林 ${ }^{27}$ は動物実験を行い， $\mathrm{B}_{1}$ 単独投与よりも クルクロン酸併用の方が肝葴中の $\mathbf{B}_{1}$ 総量が增加する といつている。更に伊藤昉はリウマチ患者に対して Bょよりもアリナミン, Cocarboxylase は低下せる血 中 $\mathrm{B}_{1}$ 值を上昇させる作用が強く, 又アリナミン投与 においても，これを中止すると次第に血中B，值は前 值に復するものであるが, コーチソンとアリナミンの 長期併用では, 投与中止後も尚, 臨床症状の改善と相 まつて血中B 1 值が改善され，クルクロン酸とアリナ ミンの併用は $\mathrm{B}_{1}$ 代謝の改善に役立ち、コーチソン, DOCA は血中B 1 值を上界させ, 尿中排泄を減少せし める,ビタミンCはこれと反対の傾向にあるといつて いる.

前述の如く，私はリウマチドック入院患者に全期間
を通じてアリナミン 1 日 $20 \mathrm{mg}$ 女服投与し，第 1 週メ ドロール $4 \mathrm{mg}$, 第 2 週ブレドニソロン $5 \mathrm{mg}$ ，第 3 週 ブタソリチン $200 \mathrm{mg}$ ，第 4 週はプレドニソロン，フ タソリヂンの低量投与下にアデノシン三燐酸 (ATP) $10 \mathrm{mg}$ 筇注を併用してみて，各薬用のB1血中濃度に 及ぼす影臂をしらべてみた。

表 9 はアリナミン $20 \mathrm{mg}$, メドロール $4 \mathrm{mg}$ を 1 週 間連続投与し，その最終日早朝空腹時アリナミン 20 $\mathrm{mg}$ 孝一度に内服させ，内服後 1 時間，及ひ24時間の 血中 $\mathrm{B}_{1}$ 濃度， 4 時間及ひ2 24 時間の $\mathrm{B}_{1}$ 尿中排泄量を測 定してみた６例の平均値を比較してみると，総 $\mathrm{B}_{1}$ 量は 1 時間值て $7.7 \mu \mathrm{g} / \mathrm{dl}$ ，24時間値て $5.7 \mu \mathrm{g} / \mathrm{dl}$ で, 治療前の $3.4 \mu \mathrm{g} / \mathrm{dl}$ に比してそれぞれ $3.3 \mu \mathrm{g} / \mathrm{dl}, 2.3$ $\mu \mathrm{g} / \mathrm{dl}$ の上昇を見せて居り, 結合型 $\mathrm{B}_{1}$ 值も 1 時間値 で $0.9 \mu \mathrm{g} / \mathrm{dl} ， 24$ 㭙間値て $1.4 \mu \mathrm{g} / \mathrm{dl}$ の上年をみた. 尿中排泄は 4 時間尿で投与量の $24.4 \%, 24$ 時間尿で55 .1\%排泄されている。

表10は同一方法で,アリナミンとブレドニソロンの 関係をみるに，総 $\mathrm{B}_{1}$ 量は，1時間值で $13.9 \mu \mathrm{g} / \mathrm{dl}$ ， 24 時間值で $8.9 \mu \mathrm{g} / \mathrm{dl}$ となり, 第 1 週の終りと比較し て $2.4 \mu \mathrm{g} / \mathrm{dl}$ 增加し，更にこれを治痛療放に比校すれ は， 2 週間の間て $5.3 \mu \mathrm{g} / \mathrm{dl}$ 增加している. 結合型 $\mathrm{B}_{1}$ 值は 1 時問後で $7.0 \mu \mathrm{g} / \mathrm{dl}, 24$ 時間後で $6.5 \mu \mathrm{g} / \mathrm{dl}$ となり，1.8 $\mu \mathrm{g} / \mathrm{dl}$ 增加し，これ又 2 週間て $4.1 \mu \mathrm{g} / \mathrm{dl}$ の増加をみた，尿中排泄ば 4 時間尿中に投与鼠の18.5 \%，24時間尿中では58.2\%の排泄を見ている。

第 1 週及び第 2 週を比較検討してみるに，（表13参

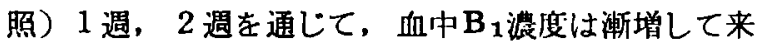
ており，大体同粎の排泄をみている。

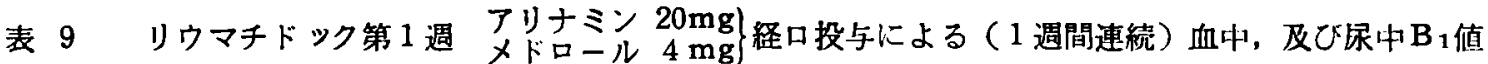

\begin{tabular}{|c|c|c|c|c|c|c|c|c|c|c|c|c|c|}
\hline \multirow{3}{*}{ 症 } & \multirow{3}{*}{ 氏 } & \multirow{3}{*}{ 名 } & \multicolumn{9}{|c|}{ 血 中 $B_{1}$ 值 $(\mu \mathrm{g} / \mathrm{dl})$} & \multicolumn{2}{|c|}{ 尿中 $\mathrm{B}_{\mathbf{1}}(\mu \mathrm{g})$} \\
\hline & & & \multicolumn{3}{|c|}{ 遊離型 $\mathrm{B}_{1}$} & \multicolumn{3}{|c|}{ 総 $B_{1}$} & \multicolumn{3}{|c|}{ 結合型 $\mathbf{B}_{\mathbf{1}}$} & \multirow{2}{*}{$\begin{array}{l}4 \text { 時間尿中 } \\
\text { 排洮：B } 1 \text { 量 }\end{array}$} & \multirow{2}{*}{$\begin{array}{l}\text { 24時間尿中 } \\
\text { 排泄 } \mathrm{B}_{1} \text { 活 }\end{array}$} \\
\hline & & & 前 & \multicolumn{2}{|c|}{ | 1 時間 $\mid 24$ 時間 } & \multirow{2}{*}{$\frac{\text { 前 }}{1.6}$} & \multicolumn{2}{|c|}{1 時間 $\mid 24$ 時間 } & \multirow{2}{*}{$\frac{\text { 前 }}{1.6}$} & \multicolumn{2}{|c|}{1 時間|24時間 } & & \\
\hline 1 & 片 & 0 & 0 & 4.0 & 2.4 & & 7.5 & 7.8 & & 3.2 & 5.4 & & 14475.0 \\
\hline 2 & 三 & 0 & 0.3 & 8.0 & 0.2 & 1.9 & 9.8 & 2.2 & 1.6 & 1.8 & 2.0 & 7441.5 & 7621.5 \\
\hline 3 & 浅 & 0 & 0.6 & 0.5 & 0.6 & 2.8 & 5.1 & 2.4 & 2.2 & 4.6 & 1.8 & 3037.5 & 10586.5 \\
\hline 4 & 北 & 0 & 0.8 & 4.4 & 0.9 & 3.8 & 7.9 & 9.8 & 3.0 & 3.6 & 3.9 & 6570.0 & 19657.0 \\
\hline 5 & 菙 & 0 & 2.4 & 3.1 & 0.3 & 7.2 & 8.4 & 8.6 & 4.8 & 5.3 & 8.3 & 2039.0 & 7218.4 \\
\hline 6 & 桜 & 0 & 1.1 & 5.2 & 1.0 & 3.0 & 15.2 & 3.2 & 1.9 & 10.0 & 2.2 & 5304.0 & 6504.0 \\
\hline & 均 & 值 & 0.9 & 4.2 & 0.9 & 3.4 & 7.7 & 5.7 & 2.5 & 3.4 & 3.9 & 4878.0 & 11010.4 \\
\hline & 均 & a & & $\begin{array}{r}(+) \\
3.3\end{array}$ & 0 & & $\begin{array}{c}(+) \\
3.3\end{array}$ & $\begin{array}{r}(+) \\
2.3\end{array}$ & & $\begin{array}{c}+(+) \\
0.9\end{array}$ & $\begin{array}{c}(+) \\
1.4\end{array}$ & $(24.4 \%)$ & $(55.1 \%)$ \\
\hline
\end{tabular}

註 各時間の値は 1 週間連続投与して, その最終日投与よりの時問を示す.（表 9 〜表12迄夙じ） 
表 10 リウマチドック 第 2 週

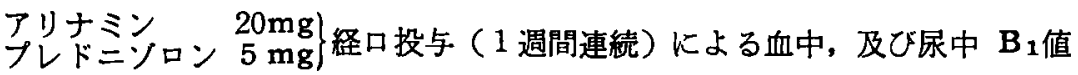

\begin{tabular}{|c|c|c|c|c|c|c|c|c|c|c|c|c|c|}
\hline \multirow{3}{*}{$\begin{array}{l}\text { 症 } \\
\text { 例 }\end{array}$} & \multirow{3}{*}{ 氏 } & \multirow{3}{*}{ 名 } & \multicolumn{9}{|c|}{ 血 中 $\mathbf{B}_{\mathbf{x}}$ 值 $(\mu \mathrm{g} / \mathrm{d} \mathbf{1})$} & \multicolumn{2}{|c|}{ 尿中 $B_{1}(\mu \mathrm{g})$} \\
\hline & & & \multicolumn{3}{|c|}{ 遊離型 $\mathrm{B}_{1}$} & \multicolumn{3}{|c|}{ 総 $B_{1}$} & \multicolumn{3}{|c|}{ 䊅合型 B 1} & \multirow{2}{*}{$\begin{array}{l}4 \text { 時間尿中 } \\
\text { 排泄 } \text { B }_{1} \text { 量 } \\
\end{array}$} & \multirow{2}{*}{$\begin{array}{l}24 \text { 時間尿中 } \\
\text { 排泄 } \mathrm{B}_{1} \text { 量 }\end{array}$} \\
\hline & & & 前 & $\mid 1$ 時間 & 24時間 & 前 & 1 時間 & 24時間 & 前 & 1 時間 & 24時間 & & \\
\hline 1 & 片 & 0 & 2.4 & 4.9 & 0 & 7.8 & 9.3 & 5.8 & 5.4 & 4.4 & 5.8 & 4824 & 7224 \\
\hline 2 & $\equiv$ & 0 & 0.2 & 1.0 & 0 & 2.2 & 9.9 & 3.6 & 2.0 & 8.9 & 3.6 & 5661 & 10770 \\
\hline 3 & 浅 & 0 & 0.6 & 6.4 & 3.5 & 2.4 & 12.2 & 12.8 & 2.0 & 5.8 & 9.3 & 6506 & 18552 \\
\hline 4 & 北 & 0 & 0.9 & 13.3 & 0.8 & 9.8 & 16.4 & 7.2 & 3.0 & 3.1 & 6.4 & 1729 & 16682 \\
\hline 5 & 横 & 0 & 0.3 & 6.6 & 1.1 & 8.6 & 15.9 & 7.4 & 8.3 & 9.3 & 6.3 & 2346 & 12147 \\
\hline 6 & 桜 & 0 & 1.0 & 0.7 & 0 & 3.2 & 8.4 & 4.9 & 2.2 & 7.7 & 4.9 & 1570 & 11640 \\
\hline 7 & 荒 & O & 1.6 & 10.5 & 4.1 & 7.4 & 18.0 & 12.6 & 5.8 & 7.5 & 8.5 & 4625 & 19004 \\
\hline 8 & 正 & 0 & 2.8 & 12.5 & 9.3 & 10.7 & 21.4 & 17.2 & 7.9 & 9.1 & 7.8 & 2830 & 8759 \\
\hline & 均 & 値 & 1.3 & 7.0 & 2.4 & 6.5 & 13.9 & 8.9 & 4.7 & 7.0 & 6.5 & 3762 & 11644 \\
\hline & 均 & 加 & & $\left|\begin{array}{r}(+) \\
5.7\end{array}\right|$ & $\begin{array}{r}(+) \\
1.1\end{array}$ & & $\begin{array}{r}(+) \\
7.4\end{array}$ & $\begin{array}{c}(+) \\
2.4\end{array}$ & & \begin{tabular}{|c|}
$(+)$ \\
2.3
\end{tabular} & \begin{tabular}{|c|}
$+(+)$ \\
1.8
\end{tabular} & $(18.5 \%)$ & $\%)$ \\
\hline
\end{tabular}

表 11 リウマチドック 第 3 週

フリナソリジン $200 \mathrm{mg}$ 経口投与 ( 1 週間連続) による血中及び尿中 B 1 值

\begin{tabular}{|c|c|c|c|c|c|c|c|c|c|c|c|c|c|}
\hline \multirow{3}{*}{$\begin{array}{l}\text { 症 } \\
\text { 例 }\end{array}$} & \multirow{3}{*}{ 氏 } & \multirow{3}{*}{ 名 } & \multicolumn{9}{|c|}{ 血 中 $B_{1}$ 値 $(\mu \mathrm{g} / \mathrm{dl})$} & \multicolumn{2}{|c|}{ 尿中 $\mathrm{B}_{1}(\mu \mathrm{g})$} \\
\hline & & & \multicolumn{3}{|c|}{ 遊離型 $\mathbf{B}_{\mathbf{1}}$} & \multicolumn{3}{|c|}{ 総 $B_{1}$} & \multicolumn{3}{|c|}{ 結合型 $\mathbf{B}_{\mathbf{1}}$} & \multirow{2}{*}{$\begin{array}{l}4 \text { 時間尿中 } \\
\text { 排泄 } \text { B }_{1} \text { 量 }\end{array}$} & \multirow{2}{*}{$\begin{array}{l}24 \text { 時間尿中 } \\
\text { 排泄 } B_{1} \text { 量 }\end{array}$} \\
\hline & & & 前 & 1 時間 & 24時間 & 前 & 1 時間 & 24時間 & 前 & 1 時間 & 24時間 & & \\
\hline 1 & 片 & 0 & 0 & 11.7 & 1.5 & 5.8 & 18.2 & 6.4 & 5.8 & 5.5 & 4.9 & 7116.2 & 11165.0 \\
\hline 2 & $\Xi$ & 0 & 0 & 4.2 & 1.6 & 3.6 & 14.2 & 6.2 & 3.6 & 10.5 & 4.6 & 5670.0 & 9464.0 \\
\hline 3 & 浅 & 0 & 3.5 & 0 & 1.9 & 12.8 & 6.6 & 8.2 & 9.3 & 6.6 & 6.3 & 3490.0 & 6524.0 \\
\hline 4 & 北 & 0 & 0.8 & 0.3 & 1.9 & 7.2 & 9.3 & 12.6 & 6.4 & 9.0 & 10.7 & 2597.4 & 15907.4 \\
\hline 5 & 滥 & 0 & 1.1 & 4.7 & 0.8 & 7.4 & 17.7 & 7.2 & 6.3 & 13.1 & 6.4 & 2507.3 & 9744.4 \\
\hline 6 & 桜 & 0 & 0 & 6.1 & 0 & 4.9 & 8.9 & 4.1 & 4.9 & 2.8 & 4.1 & $4218^{\circ} 0$ & 8147.0 \\
\hline 7 & 筦 & 0 & 4.1 & 5.6 & 1.6 & 12.6 & 11.5 & 7.4 & 8.5 & 5.9 & 5.8 & 3850.0 & 16350.3 \\
\hline 8 & 正 & 0 & 9.3 & 2.0 & 2.8 & 17.2 & 10.6 & 10.7 & 7.8 & 8.6 & 7.9 & 2188.8 & 6148.3 \\
\hline 平 & 均 & 値 & 2.4 & 4.3 & 1.5 & 8.9 & 12.1 & 7.8 & 6.5 & 7.8 & 6.3 & 3954.7 & 10431.3 \\
\hline$T$ & 均 & 減 & & $\begin{array}{r}(+) \\
1.9\end{array} \mid$ & $\begin{array}{c}(-\overrightarrow{)}) \\
0.9\end{array}$ & & $\begin{array}{c}(+) \\
3.2\end{array}$ & $(-)$ & & $\begin{array}{r}(+) \\
1.3\end{array}$ & $(-)$ & $(19.8 \%)$ & $(52.2 \%)$ \\
\hline
\end{tabular}

さて第 3 週はブタソリヂンとの併用療法を行い，前 者と闰様に測定してみた。表 11 の如く，総B 1 量は内 服 1 時間後で $12.1 \mu \mathrm{g} / \mathrm{dl}, 24$ 時間後で $7.8 \mu \mathrm{g} / \mathrm{d} 1$ とな り，治療前に比すればそれぞれ，8.5 $\mu \mathrm{g} / \mathrm{d} 1,4.2 \mu \mathrm{g} / \mathrm{d} 1$ の增加を見ているか，第 2 週の終りの血中濃度に比す れば，総 $\mathrm{B}_{1}$ 孯は逆に $1.1 \mu \mathrm{g} / \mathrm{dl}$ の減少を見た，又結 合型 $B_{1}$ についても同栐の経過が見られ，24時間值で は, 第 2 週即ちブレドニソロン, フリナミン併用時よ
りも $0.2 \mu \mathrm{g} / \mathrm{dl}$ の減少を示している. 尿中排泄は 4 時 間尿で投与量の約 $19.8 \%, 24$ 時間尿で $52.2 \%$, 前 2 週 に比して有意の差は認められなかつた.

第 4 週は, 副腎皮質ホルモン,ブタソリジンの低量 投与下に, アリナミン $20 \mathrm{mg}$ の外にアデノシン三燐酸 （A T P ) $10 \mathrm{mg}$ 波下泩射して行つてみた。即ち早朝 空腹時, アリナミン $20 \mathrm{mg}$ 内服後, 30 分の後に ATP $10 \mathrm{mg}$ 筋注し，それぞれ内服後 1 時間（ATP 皮下 
5016

注射後30分) 及び24時間後の血中 B 1 值,並びに 4 時間 尿及ひ24時間尿に於ける $\mathrm{B}_{1}$ 排泄量を測定してみた。 即与 表12，13に示す如く，総 $\mathbf{B}_{1}$ 量は 1 時間及び24時 間後でそれそれれ $8.8 \mu \mathrm{g} / \mathrm{dl}, 8.2 \mu \mathrm{g} / \mathrm{dl}$ と大差はないが， 遊離型 $\mathrm{B}_{1}$ が， 1 時間後で $4.6 \mu \mathrm{g} / \mathrm{dl}$ と上年している のが,24時間後に $0.4 \mu \mathrm{g} / \mathrm{dl}$ と減少し, 前週に比し 0.9 $\mu \mathrm{g} / \mathrm{dl}$ も减少し, 更に治療前に比しても $0.5 \mu \mathrm{g} / \mathrm{dl} の$ 减少を見ている．従つて結合型 $\mathbf{B}_{1}$ は，内服後 1 時間 後では $4.2 \%$,むしろ減少しているにも関わらず,24 時間値では $7.8 \mu \mathrm{g} / \mathrm{dl}$ となり前週に比し $2.6 \mu \mathrm{g} / \mathrm{dl}$, 更 に治療前に比しても $5.3 \mu \mathrm{g} / \mathrm{dl}$ と著しく上昇をみせて いる.

[小括] $\mathrm{B}_{1}$ 血中漊度に対して，ブレドニソロン， メドロールは $\mathbf{B}_{1}$ の尿中排泄をやや减少させかつ $\mathbf{B}_{1}$ 血 中清度を上䄯させるが，フタソリジンは逆にB1血中 浱度を減少させた。而してAＴＰ併用は，総 $\mathrm{B}_{1}$ 値の 高度の上䄯は見られないにも関わらす，遊離型 $\mathrm{B}_{1}$ が 著しく减少し，結合型 $B_{1}$ の著しい上年を示してい
る.即ち従来云わ扎ている如く， $\mathbf{B}_{1}$ の生理作用はピ 口燐酸エステルの型で発揮され，生体内に於ける附燐 作用はATPから供給されると考えられているが，A TP 併用により，結合型B1の著增はこれを蓑付けて いる・

\section{第 3 節 血中 $\mathbf{B}_{1}$ 值と医床症状との閣係}

表14は上記期問中の臨床諸検查の成績を示す.（1 〜 6 症例). 即ち 1 週, 2 週はメドロール,プレドニソ ロンとアリナミンとの併用により, 多くの場合, 疼痛 は改善され，赤血球数も增加を見て居り，へモクロビ ンも軽度ではあるが增加の傾向が見うけられる, 又赤 沈值，肝機能も改善が見られ，血中 $\mathbf{B}_{1}$ 值の上界とそ の経過を同じくしている。

これに反し，第 3 週のブタソリジンは，リウマチの 疼痛に対しては有効に作用しているが， 6 例中 5 例に 赤血球数の低下が見られ，3 例に赤沈值の再立進, 更 に肝機能障碍の亢進が 4 例に見られた。血中B 1 值は 前述の如くこの週では低下して居り，肝機能障碍の再

表 12 リウマチドック 第 4 週

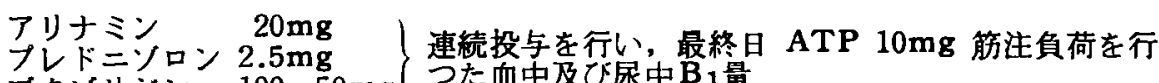

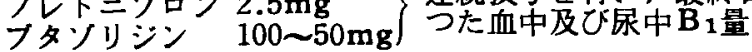

\begin{tabular}{|c|c|c|c|c|c|c|c|c|c|c|c|c|c|}
\hline \multirow{3}{*}{ 症 } & \multirow{3}{*}{ 氏 } & \multirow{3}{*}{ 名 } & \multicolumn{9}{|c|}{ 血 中 $B_{1}$ 值 $(\mu \mathrm{g} / \mathrm{dl})$} & \multicolumn{2}{|c|}{ 尿中B $1(\mu \mathrm{g})$} \\
\hline & & & \multicolumn{3}{|c|}{ 遊離型 $\mathbf{B}_{\mathbf{1}}$} & \multicolumn{3}{|c|}{ 総 $\mathbf{B}_{1}$} & \multicolumn{3}{|c|}{ 結合型 $\mathbf{B}_{\mathbf{1}}$} & \multirow{2}{*}{$\begin{array}{l}4 \text { 時間尿中 } \\
\text { 排泄 } \mathrm{B}_{1} \text { 量 }\end{array}$} & \multirow{2}{*}{$\begin{array}{l}\text { 24時間尿中 } \\
\text { 排泄 } \mathrm{B}_{1} \text { 量 }\end{array}$} \\
\hline & & & 前 & 1 時間 & 24時間 & 前 & 1 時間 & 24時間 & 前 & 1 時間 & 24 時間 & & \\
\hline 1 & $\pi^{\prime}$ & 0 & 1.5 & 5.8 & 0 & 6.4 & 7.9 & 8.5 & 4.9 & 2.1 & 8.5 & 4665.2 & 12140.0 \\
\hline 2 & $\equiv$ & 0 & 1.6 & 6.1 & 0 & 6.2 & 8.4 & 7.0 & 4.6 & 2.3 & 7.0 & 2675.0 & 7664.6 \\
\hline 3 & 线 & 0 & 1.9 & 2.0 & 0.9 & 8.2 & 11.6 & 8.0 & 6.3 & 9.6 & 7.1 & 2625.0 & 12786.0 \\
\hline 4 & 北 & 0 & 1.9 & 0.8 & 1.1 & 12.6 & 3.7 & 7.4 & 10.7 & 2.9 & 6.3 & 3596.0 & 10946.0 \\
\hline 5 & 滥 & 0 & 0.8 & 8.3 & 0.3 & 7.2 & 14.8 & 12.9 & 6.4 & 6.5 & 12.9 & 4060.0 & 19207.0 \\
\hline 6 & 桜 & 0 & 0 & 4.5 & 0.3 & 4.1 & 10.2 & 5.0 & 4.1 & 5.7 & 4.7 & 4830.0 & 10158.4 \\
\hline 5 & 坞 & 值 & 1.3 & 4.6 & 0.4 & 7.5 & 8.8 & 8.2 & 6.2 & 4.2 & 7.8 & 4056.3 & 12132.4 \\
\hline & 均 & 減 & & $\begin{array}{r}(+) \\
3.3\end{array}$ & $\left(\begin{array}{c}(-) \\
0.9\end{array}\right.$ & & $\begin{array}{c}(+) \\
1.3\end{array}$ & $\begin{array}{c}(+) \\
0.7\end{array}$ & & $\begin{array}{r}(-) \\
2.0\end{array}$ & $\begin{array}{r}(+) \\
2.6\end{array}$ & $(20.3 \%)$ & $(60.6 \%)$ \\
\hline
\end{tabular}

表 13 リウマチドック各週に於ける24時間平均值（血中及ひ尿中）の比較（表 9 12参照）

\begin{tabular}{|c|c|c|c|c|c|c|c|c|c|}
\hline \multirow{3}{*}{$\begin{array}{l}\text { リウマチ } \\
\text { ドック } \\
\text { 週 }\end{array}$} & \multicolumn{8}{|c|}{ 血 中 $\mathrm{B}_{1}$ 增减 值 $(\mu \mathrm{g} / \mathrm{d} \mathrm{l})$} & \multirow{3}{*}{$\begin{array}{c}\text { 24時間尿中排泄 } \\
\text { B 1 量 } \\
(\%)\end{array}$} \\
\hline & \multicolumn{4}{|c|}{ 治療開始前との比較 } & \multicolumn{4}{|c|}{ 入院時との比较 } & \\
\hline & 遊離型 $\mathrm{B}_{\mathbf{1}}$ & 総 & $\mathbf{B}_{\mathbf{1}}$ & 結合型 $\mathbf{B}_{1}$ & 遊離型 $\mathrm{B}_{1}$ & 総 & $\mathbf{B}_{\mathbf{1}}$ & 結合型 $\mathbf{B}_{\mathbf{1}}$ & \\
\hline 1 & 0 & +2 & 2.3 & $+\quad 1.4$ & 0 & + & 2.3 & +1.4 & 55.1 \\
\hline 2 & +1.1 & & 2.4 & +1.8 & +1.2 & + & 5.3 & +4.1 & 58.2 \\
\hline 3 & $(-) 0.9$ & $(-) 1$ & 1.1 & $(-) 0.2$ & +0.3 & + & 4.2 & +3.9 & 52.2 \\
\hline 4 & $(-) 0.9$ & $+c$ & 0.7 & +2.6 & $(-) 0.5$ & + & 3.8 & +5.3 & 60.6 \\
\hline
\end{tabular}


え進がこの結果を裏付けしている.

[小括] 副堅皮質ホルモンと $\mathrm{B}_{1}$ の併用療法は，疼 痛の軽减と共に, 負血, 赤沈値, 肝機能に有利的に作 用するが，ブタソリジン，B1併用では，疼痡の軽减 は見られても，貧血の再現, 赤沈值の再六進, 肝機能
障害の再発が見られ，血中 $\mathbf{B}_{1}$ 值も低下している。 又 副腎皮質ホルモン, ブタソリジン低量投与下にアリナ ミンA T P の併用は臨床症状を好転させ,又結合型 B 1 值を上界させた。

表 14

リウマチドック各週に於ける踄床検査成績

\begin{tabular}{|c|c|c|c|c|c|c|c|c|c|c|c|c|}
\hline 症例 & 氏 & 名 & Stage & Class & 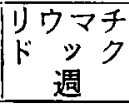 & $\begin{array}{c}\text { 疼 痛 } \\
(\%)\end{array}$ & \begin{tabular}{|c} 
赤血球数 \\
$($ 万
\end{tabular} & 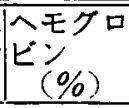 & $\begin{array}{c}\text { 赤沈 值 } \\
(\mathrm{m} \mathrm{m})\end{array}$ & $\mid \begin{array}{l}\text { 厡中ウロ } \\
\text { ゲリノー } \\
\text { ゲン }\end{array}$ & 高 田 & $\begin{array}{l}\text { ヘパトサ } \\
\text { ルフフレ } \\
\text { イン } \%\end{array}$ \\
\hline \multirow{5}{*}{1} & \multirow{5}{*}{ 片 } & \multirow{5}{*}{0} & \multirow{5}{*}{2} & \multirow{5}{*}{2} & 前 & 100 & 350 & 67 & $82 \sim 113$ & $(+)$ & $\mathrm{HH}$ & 5 \\
\hline & & & & & 1 週 & 60 & 344 & 70 & $49 \sim 87$ & $(+)$ & H & 5 \\
\hline & & & & & 2 週 & 50 & 390 & 74 & $37 \sim 70$ & $(+)$ & + & 5 \\
\hline & & & & & 3 週 & 50 & 330 & 65 & $28 \sim 70$ & $(+)$ & \pm & 7.5 \\
\hline & & & & & 4 週 & 40 & 375 & - 72 & $18 \sim 45$ & $(+)$ & - & 4 \\
\hline \multirow{5}{*}{2} & \multirow{5}{*}{$\equiv$} & \multirow{5}{*}{0} & \multirow{5}{*}{2} & \multirow{5}{*}{2} & 前 & 100 & 415 & 71 & $43 \sim 60$ & $(+)$ & - & 5 \\
\hline & & & & & 1 週 & 80 & 410 & 78 & $24 \sim 49$ & $(+)$ & - & 2.5 \\
\hline & & & & & 2 週 & 70 & 408 & 73 & $47 \sim 77$ & $(+)$ & - & 5 \\
\hline & & & & & 3 週 & 60 & 388 & 74 & $25 \sim 61$ & $(+)$ & \pm & 15 \\
\hline & & & & & 4 週 & 50 & 313 & 73 & $49 \sim 76$ & $(+)$ & - & 5 \\
\hline
\end{tabular}

\begin{tabular}{|c|c|c|c|c|c|c|c|c|c|c|c|c|}
\hline \multirow{5}{*}{3} & \multirow{5}{*}{ 浅 } & \multirow{5}{*}{0} & \multirow{5}{*}{3} & \multirow{5}{*}{2} & 前 & 100 & 350 & 63 & $111 \sim 136$ & $H \sim H$ & \pm & 5 \\
\hline & & & & & 1 週 & 50 & 395 & 74 & $75 \sim 112$ & $H$ & $H$ & 13 \\
\hline & & & & & 2 週 & 50 & 411 & 72 & $102 \sim 124$ & $H$ & \pm & 5 \\
\hline & & & & & 3 週 & 50 & 308 & 68 & $115 \sim 139$ & + & $H$ & 6 \\
\hline & & & & & 4 週 & 40 & 333 & 78 & $116 \sim 139$ & $(+)$ & + & 0 \\
\hline
\end{tabular}

\begin{tabular}{|c|c|c|c|c|c|c|c|c|c|c|c|c|}
\hline \multirow{5}{*}{4} & \multirow{5}{*}{ 北 } & \multirow{5}{*}{0} & \multirow{5}{*}{3} & \multirow{5}{*}{3} & 前 & 100 & 320 & 68 & $68 \sim 86$ & $(+)$ & H & 5 \\
\hline & & & & & 1 週 & 90 & 360 & 73 & & $(+)$ & $H$ & 2.5 \\
\hline & & & & & 2 週 & 90 & 370 & 73 & $23 \sim 53$ & $(+)$ & \pm & 0 \\
\hline & & & & & 3 遇 & 90 & 310 & 74 & $58 \sim 76$ & $(+)$ & H & 2.5 \\
\hline & & & & & 4 週 & 90 & 360 & 67 & & $(+)$ & - & 4 \\
\hline
\end{tabular}

\begin{tabular}{|c|c|c|c|c|c|c|c|c|c|c|c|c|}
\hline \multirow{5}{*}{5} & & \multirow{5}{*}{0} & \multirow{5}{*}{2} & \multirow{5}{*}{2} & 前 & 100 & 520 & 93 & $10 \sim 28$ & $(+)$ & - & 2.5 \\
\hline & & & & & 1 週 & 50 & 525 & 95 & $8 \sim 24$ & $(+)$ & + & 5 \\
\hline & & & & & 2 週 & 40 & 450 & 100 & $2 \sim 16$ & $(+)$ & - & 5 \\
\hline & & & & & 3 週 & 40 & 420 & 95 & $2 \sim 13$ & $(+)$ & - & 12.5 \\
\hline & & & & & 4 週 & 30 & 516 & 90 & $8 \sim 21$ & $(+)$ & - & 12.5 \\
\hline
\end{tabular}

\begin{tabular}{|c|c|c|c|c|c|c|c|c|c|c|c|c|}
\hline \multirow{5}{*}{6} & \multirow{5}{*}{ 桜 } & \multirow{5}{*}{$\mathrm{O}$} & \multirow{5}{*}{2} & \multirow{5}{*}{2} & 前 & 100 & 470 & 70 & $63 \sim 108$ & $(+)$ & \pm & 5 \\
\hline & & & & & 1 週 & 70 & 420 & 65 & $42 \sim 84$ & $(+)$ & H & 2.5 \\
\hline & & & & & 2 週 & 70 & 450 & 65 & $91 \sim 116$ & $(+)$ & \pm & 8 \\
\hline & & & & & 3 週 & 70 & 450 & 70 & $78 \sim 123$ & H & + & 3 \\
\hline & & & & & 4 週 & 60 & 420 & 65 & $18 \sim 107$ & $H$ & $H$ & 12.5 \\
\hline
\end{tabular}

（註）：疼痛の\%は入院時将痛を100とし無痛時を０として患者自身に表現させた。 


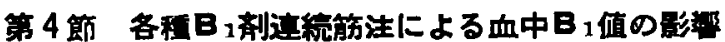

表 15 は関節リウマチ患者に $\mathbf{B}_{1}$, アリナミン及び Cocarboxylase を連続 1 週間筋注して30分及ひ24時 間後の血中濃度を比較してみた．即ちB $10 \mathrm{mg}$ 筇注 では, 血中総B 1 值は, 使用前の $2.1 \mu \mathrm{g} / \mathrm{dl}$ から, 筋注 後 30 分で $18.1 \mu \mathrm{g} / \mathrm{dl}, 24$ 時間後では $4.6 \mu \mathrm{g} / \mathrm{dl}$ となり， $2.5 \mu \mathrm{g} / \mathrm{d} 1$ の增加があり，結合型B1はそれぞれ，1.6 $\mu \mathrm{g}$ $/ \mathrm{dl}$ が30分後で $4.8 \mu \mathrm{g} / \mathrm{dl}, 24$ 時間後で $1.1 \mu \mathrm{g} / \mathrm{dl}$ の 增加を見ている．尿中排泄は 3 時間で投与量の $40 \%$ ， 24時間で69\%の排泄を見た。

同様にしてアリナミン $10 \mathrm{mg}$ で行つてみるに， 総
$\mathrm{B}_{1}$ 值は，使用前の $2.1 \mu \mathrm{g} / \mathrm{dl}$ から，筋注後30分で57.8 $\mu \mathrm{g} / \mathrm{dl}$ と大幅の増加を示すが，24特間後には $5.6 \mu \mathrm{g} / \mathrm{dl}$ となり，3.5 $\mu \mathrm{g} / \mathrm{dl}$ の增加となつている。尿中排泄は 3 時間尿で投与量の約 $24.4 \%$, と前者 ( $\left.\mathrm{B}_{1}\right)$ に比し て少いが，24時間尿では62.5\%と前者に比し大差が認 められない。

Cocarboxylase は筇注後30分の血中総 $\mathrm{B}_{1}$ 値は29.6 $\mu \mathrm{g} / \mathrm{dl}$ で,前 2 者（B1 及びアリナミン）のほぼ中間值 を示しているが，結合型B 1 値は，筋注後30分で 11.7 $\mu \mathrm{g} / \mathrm{dl}$ ，24時間值で $6.8 \mu \mathrm{g} / \mathrm{dl}$ とそれそれ $8.6 \mu \mathrm{g} / \mathrm{dl}$, $3.7 \mu \mathrm{g} / \mathrm{d} 1$ の增加を見せ，前 2 者に比して結合型 $\mathrm{B}_{1}$ の

表 15 各種 $\mathrm{B}$ 剤 $10 \mathrm{mg} ， 1$ 週間連続筋注による血中尿度及び尿中排泄量（関節リウマチ患者）

a)メタボリン $10 \mathrm{mg}$ 筇注

\begin{tabular}{|c|c|c|c|c|c|c|c|c|c|c|c|c|c|}
\hline \multirow{3}{*}{$\begin{array}{l}\text { 症 } \\
\text { 例 }\end{array}$} & \multirow{3}{*}{ 氏 } & \multirow{3}{*}{ 名 } & \multicolumn{9}{|c|}{ 血中 $\mathrm{B}_{1}$ 値 $(\mu \mathrm{g} / \mathrm{dl})$} & \multicolumn{2}{|c|}{ 尿中 $\mathrm{B}_{\mathrm{I}}(\mu \mathrm{g})$} \\
\hline & & & \multicolumn{3}{|c|}{ 遊離型 $\mathrm{B}_{\mathbf{1}}$} & \multicolumn{3}{|c|}{ 総 $\mathbf{B}_{1}$} & \multicolumn{3}{|c|}{ 結合型 $\mathbf{B}_{1}$} & 3 時間尿中 & 24時間尿中 \\
\hline & & & 前 & 30 分 & 24時間 & 前 & 30 分 & |24時間 & 前 & 30 分 & 24時間 & 排 泄 量 & 排 泄 量 \\
\hline 1 & 後 & 0 & 1.0 & 19.2 & 1.4 & 3.0 & 23.5 & 3.8 & 2.0 & 4.3 & 2.4 & 4010 & 6982 \\
\hline 2 & 田 & 0 & 0 & 7.2 & 2.4 & 1.2 & 12.6 & 5.4 & 1.2 & 5.4 & 3.0 & 3982 & 6760 \\
\hline \multicolumn{2}{|c|}{ 平 } & 値 & 0.5 & 13.2 & 1.9 & 2.1 & 18.1 & 4.6 & 1.6 & 4.8 & 2.7 & 3996 & 6871 \\
\hline & 均 & 加 & & $\begin{array}{l}(+) \\
12.7\end{array}$ & $\begin{array}{l}(+) \\
1.4\end{array}$ & & $\begin{array}{r}(+) \\
6.5\end{array}$ & $\begin{array}{c}(+) \\
2.5\end{array}$ & & $\begin{array}{r}(++) \\
3.2\end{array}$ & $\begin{array}{r}(+) \\
1.1\end{array}$ & $(40 \%)$ & $(69 \%)$ \\
\hline
\end{tabular}

b) アリナミン $10 \mathrm{mg}$ 筋注

\begin{tabular}{|c|c|c|c|c|c|c|c|c|c|c|c|c|c|}
\hline \multirow{3}{*}{$\begin{array}{l}\text { 症 } \\
\text { 例 }\end{array}$} & \multirow{3}{*}{ 氏 } & \multirow{3}{*}{ 名 } & \multicolumn{9}{|c|}{ 血 中 $B_{1}$ 値 $(\mu \mathrm{g} / \mathrm{dl})$} & \multicolumn{2}{|c|}{ 尿中 $\mathbf{B}_{1}(\mu \mathrm{g})$} \\
\hline & & & \multicolumn{3}{|c|}{ 遊離型 $\mathbf{B}_{1}$} & \multicolumn{3}{|c|}{ 総B1 } & \multicolumn{3}{|c|}{ 結合型 $\mathbf{B}_{1}$} & 3 時間尿中 & 24時間尿中 \\
\hline & & & 前 & 30 分 & |24時間 $\mid$ & 前 & 30 分 & $\mid 24$ 時間 $\mid$ & 前 & 30 分 & 24時間 & 排 泄 量 & 排 泄 量 \\
\hline 1 & 後 & 0 & 1.0 & 55.5 & 1.5 & 3.0 & 61.0 & 4.6 & 2.0 & 6.1 & 3.5 & 2250 & 6375 \\
\hline 2 & 田 & 0 & 0 & 48.2 & 1.7 & 1.2 & 58.8 & 6.5 & 1.2 & 6.5 & 4.8 & 2620 & 6120 \\
\hline \multicolumn{2}{|c|}{ 平 } & 値 & 0.5 & 51.8 & 1.6 & 2.1 & 59.9 & 5.6 & 1.6 & 6.3 & 4.1 & 2435 & 6248 \\
\hline & 均 & 加 & & $\begin{array}{l}(+) \\
51.3\end{array}$ & $\begin{array}{c}(+) \\
1.1\end{array}$ & & $\begin{array}{l}(+) \\
57.8\end{array}$ & $\begin{array}{r}(+) \\
3.5\end{array}$ & & $\begin{array}{r}(+) \\
4.7\end{array}$ & $\begin{array}{r}(+) \\
2.5\end{array}$ & $(24.4 \%)$ & $(62.5 \%)$ \\
\hline
\end{tabular}

c) Cocarboxylase $10 \mathrm{mg}$ 筋注

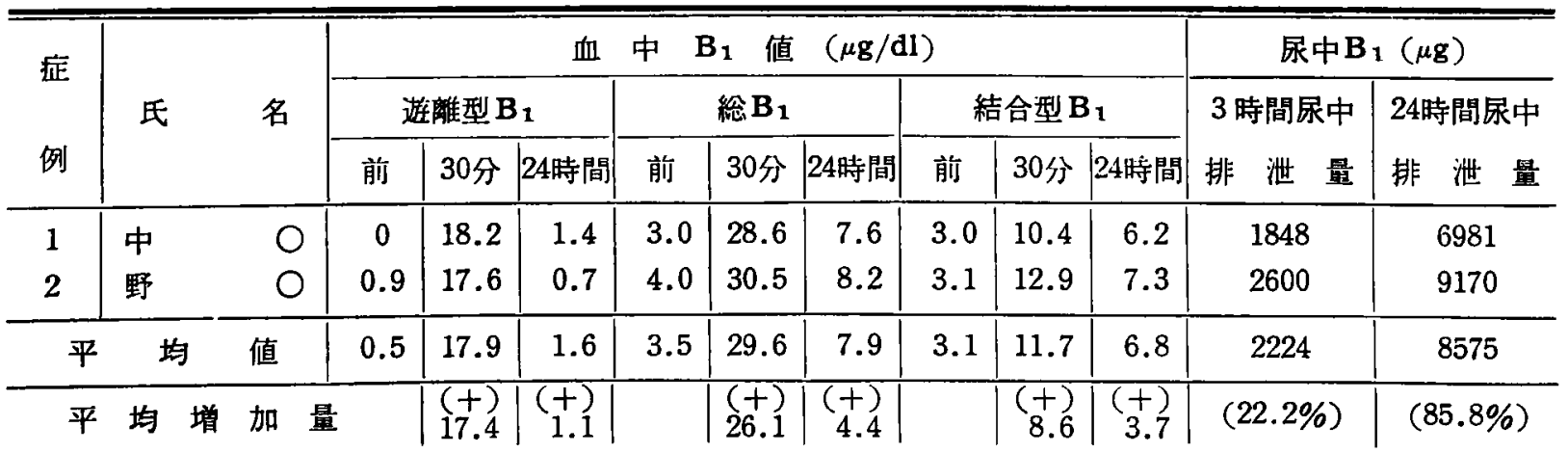

註）各時間の值は連続 1 週間投与後，その最終投与よりの時間を示す。（表15, 及じ16） 
著しい增加が見られた。（図 5 ，参照）

対象群として腰痛症患者に $\mathbf{B}_{1}$ 及びリリ ミン $10 \mathrm{mg}$ 連続投与してみたが, 岡㥞に $\mathrm{B}_{1}$ に比してアリナミンは著しく血中総 $\mathrm{B}_{1}$ 値を 上䄯させるが，遊離型 $\mathrm{B}_{1}$ の上年が多く，結 合型 $\mathrm{B}_{1}$ の上年はあまり見られなかつた.

(表16及び図 6 参照).

[小括] 上記 3 者 ( $\mathrm{B}_{1}$, アリナミン, $\mathrm{Co}-$ carboxylase）の投与実験を比較してみる に，筋注30分後での血中浱度は，アリナミン が著しく急上界を示しているが，24時間値で は 3 者の間で大差はない，総B1量の增加は Cocarboxylase, アリナミンがほほ同様に 上年し， B 14前 2 者に比してやや少小，又 結合型 B1の上年は Cocarboxylase 投与が 最高で、アリナミンがこれに次ぎBがー番 少小。
図 5 各種 B 1 剂10mg 1 週間連続筇注による血中泱度 及び尿中排渫量（関節リウマチ患者）
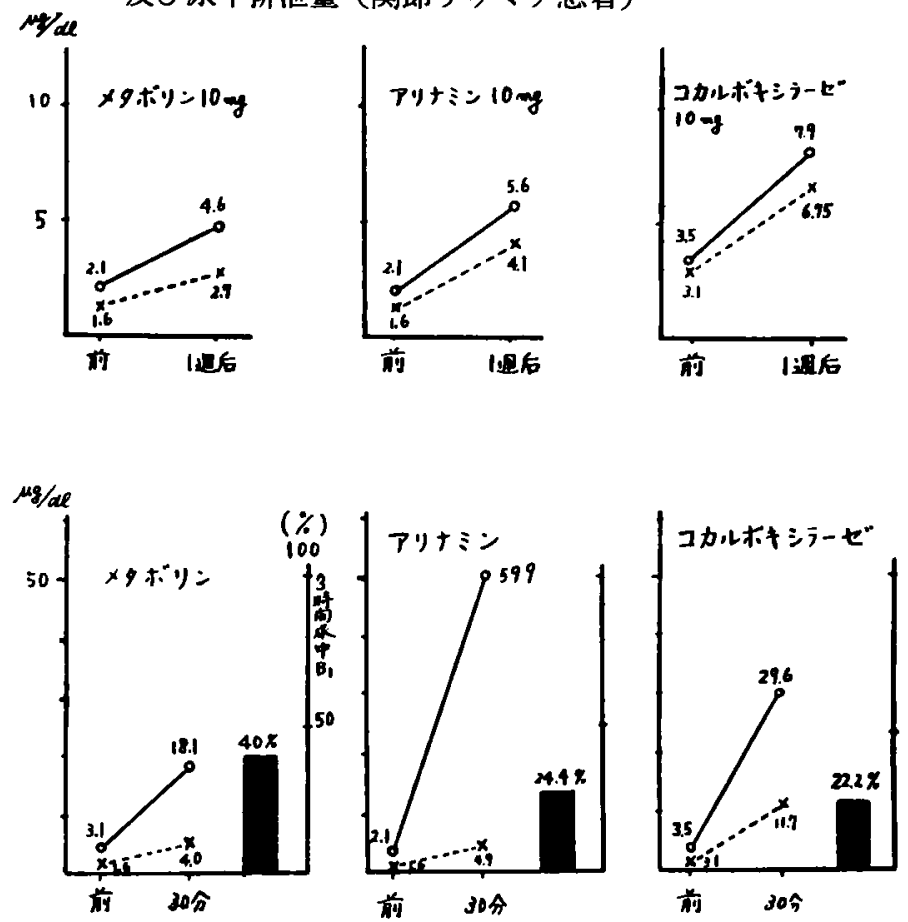

表 16 各種 $\mathbf{B}_{1}$ 郕 1 週間連連続筋注による血中濃度及び尿中排泄量（腰痡症患者）

a) メタボリン $10 \mathrm{mg}$ 筋注

\begin{tabular}{|c|c|c|c|c|c|c|c|c|c|c|c|c|c|}
\hline \multirow{3}{*}{$\begin{array}{l}\text { 症 } \\
\text { 例 }\end{array}$} & \multirow{3}{*}{ 氏 } & \multirow{3}{*}{ 名 } & \multicolumn{9}{|c|}{ 血 中 $\mathrm{B}_{1}$ 値 $(\mu \mathrm{g} / \mathrm{d} \mathrm{l})$} & \multicolumn{2}{|c|}{ 尿中 $B_{1}(\mu g)$} \\
\hline & & & \multicolumn{3}{|c|}{ 遊離型 $\mathrm{B}_{\mathbf{1}}$} & \multicolumn{3}{|c|}{ 総 $B_{1}$} & \multicolumn{3}{|c|}{ 結合型 $\mathbf{B}_{\mathbf{1}}$} & 3 時間尿中 & 24時間尿中 \\
\hline & & & 前 & 30 分 & 24時間 & 前 & 30 分 & 24時間 & 前 & 30 分 & 24時間 & 排 泄 量 & 排 泄 量 \\
\hline 1 & 0 & 川 & 0 & 3.5 & 5.9 & 2.2 & 10.6 & 7.9 & 2.2 & 7.1 & 2.0 & 5819 & 6463 \\
\hline 2 & 中 & O & 0 & 7.9 & 8.0 & 2.0 & 16.0 & 9.8 & 2.0 & 8.1 & 1.8 & 2517 & 9300 \\
\hline 3 & 0 & 島 & 1.5 & 21.8 & 1.0 & 2.6 & 34.8 & 3.2 & 0.9 & 13.0 & 2.2 & - & - \\
\hline 5 & 均 & 値 & 0.5 & 11.1 & 5.0 & 2.3 & 20.5 & 7.0 & 1.8 & 9.4 & 2.0 & 6141 & 7881 \\
\hline & 均 & 加 & & $\begin{array}{r}(+) \\
9.6\end{array}$ & $\begin{array}{r}(+) \\
4.5\end{array}$ & & $\begin{array}{l}(+) \\
17.2\end{array}$ & $\begin{array}{r}(+) \\
4.7\end{array}$ & & $\begin{array}{l}(+) \\
7.0\end{array}$ & $\mid \begin{array}{r}(+) \\
0.2\end{array}$ & $(61.4 \%)$ & $(78.8 \%)$ \\
\hline
\end{tabular}

b ) アリナミン $10 \mathrm{mg}$ 筋注

\begin{tabular}{|c|c|c|c|c|c|c|c|c|c|c|c|c|c|}
\hline \multirow{3}{*}{$\begin{array}{l}\text { 症 } \\
\text { 例 }\end{array}$} & \multirow{3}{*}{ 氏 } & \multirow{3}{*}{ 名 } & \multicolumn{9}{|c|}{ 血 中 $\mathrm{B}_{1}$ 值 $(\mu \mathrm{g} / \mathrm{d} \mathrm{l})$} & \multicolumn{2}{|c|}{ 尿中 $\mathrm{B}_{1}(\mu \mathrm{g})$} \\
\hline & & & \multicolumn{3}{|c|}{ 遊離型 $\mathrm{B}_{1}$} & \multicolumn{3}{|c|}{ 総 $B_{1}$} & \multicolumn{3}{|c|}{ 結合型 $\mathbf{B}_{1}$} & 3 時間尿中 & 24 時閥尿中 \\
\hline & & & 前 & 30 分 & 24時問 & 前 & 30 分 & 24時間 & 前 & 30 分 & 24時間 & 排 泄 量 & 排 洺 量 \\
\hline 1 & 0 & 川 & 0 & 21.8 & 3.3 & 2.2 & 34.2 & 5.4 & 2.2 & 12.5 & 2.1 & 908.8 & 2242.5 \\
\hline 2 & 中 & 0 & 0 & 86.4 & 7.6 & 2.0 & 93.8 & 9.8 & 2.2 & 7.4 & 2.2 & 3245 & 3562.5 \\
\hline 3 & 0 & 島 & 1.5 & 57.0 & 12.6 & 2.6 & 68.3 & 23.2 & 0.9 & 11.3 & 10.6 & - & 一 \\
\hline & 世 & 值 & 0.5 & 55.1 & 7.8 & 2.3 & 65.4 & 12.8 & 1.8 & 10.4 & 5.0 & 2076.9 & 2235 \\
\hline & 均 & 加 & & $\begin{array}{l}(+) \\
54.6\end{array}$ & $\begin{array}{r}(+) \\
7.3\end{array}$ & & $\begin{array}{l}(+) \\
63.1\end{array}$ & $\begin{array}{l}(+) \\
10.5\end{array}$ & & $\begin{array}{r}(+) \\
8.6\end{array}$ & $\begin{array}{r}(+) \\
3.2\end{array}$ & $(20.8 \%)$ & $(22.4 \%)$ \\
\hline
\end{tabular}


図6 各種 B 1 郕10 mg 1 週間連続筋注によ

リウマチー般症状の改善に役立つものと考えられる。 る血中浱度及ひ尿中排泄量（健康人）
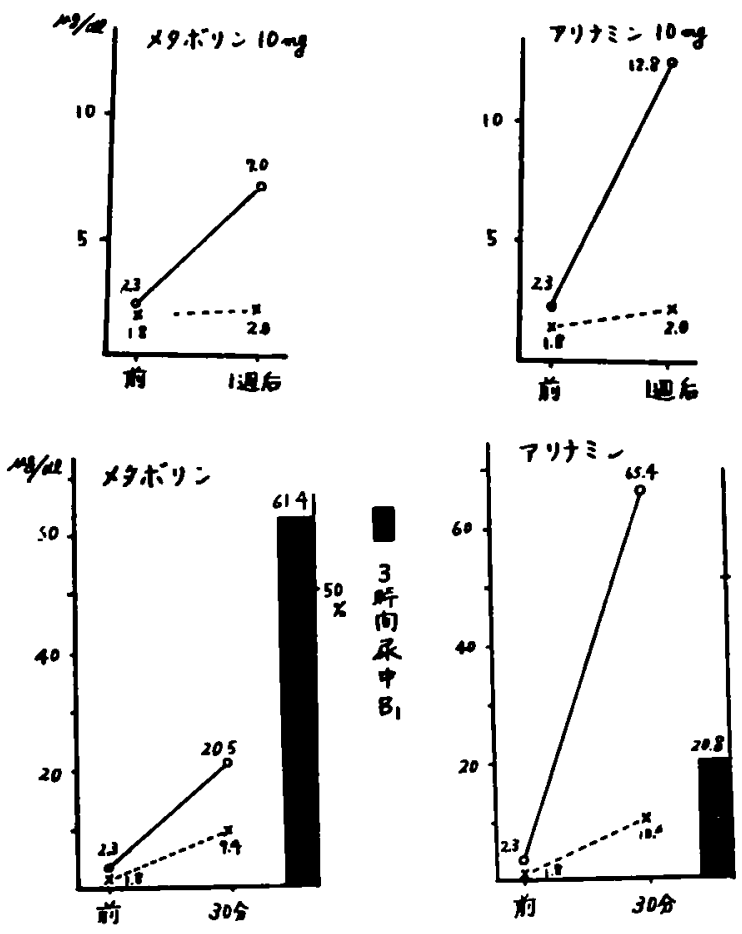

第 5 節 アリナミン低贵这綂投与による血中日1值 の影帮（副堅皮質ホルモン治療下に於て）

前述の如く関節リウマチ患者は肝機能障碍岸伴うも のが多く， $\mathrm{B}_{1}$ 利用不全に基く血中 $\mathrm{B}_{1}$ 値の低下が考え られるが，大量投与にも関わらす抗りウマチ剂によつ てB1血中港度は変動を受けている.

リウマチドックに入院せる関節リウマチ患者18例に つき，副腎皮質ホルモン治療と併用して，アリナミン 1 日量 $5 \mathrm{mg}$ の投与 1 䓢間連続して行い, 1 週間後 の血中B1値の上年を検討してみた．表17の如く18例 の平均値は，総 $\mathrm{B}_{1}$ 値で投与前 $5.3 \mu \mathrm{g} / \mathrm{dl}$ が $7.5 \mu \mathrm{g} / \mathrm{dl}$ と $2.2 \mu \mathrm{g} / \mathrm{dl}$ の增加が見られ，又結合型 $\mathrm{B}_{1}$ 值も投与 前の $4.6 \mu \mathrm{g} / \mathrm{dl}$ が $6.3 \mu \mathrm{g} / \mathrm{dl}$ となり, $1.7 \mu \mathrm{g} / \mathrm{dl}$ 增加し ている. 表18は対象群として正常健康人 6 例について 行つてみたが, 同様に総 $\mathrm{B}_{1}$ 值で $1.9 \mu \mathrm{g} / \mathrm{dl}$, 結合型 $\mathrm{B}_{1}$ 值て $0.8 \mu \mathrm{g} / \mathrm{d} l$ の增加が見られた.

〔小括〕前述の如くリウマチドックに於ける臨床症 状と血中B 1 值との関連性については，B1大量投与に よつて一時的に血中濃度の上年を見ても, 各種抗り ウマチ訪の投与を中止すれば，疼痛曲線は上年を見せ ている．副腎皮質ホルモン投与のもとでB1の低量投 与によつても，その血中B1值は上年を示している， 即ち従来の如く $\mathrm{B}_{1}$ のみの大量投与よりも，副腎皮質 ホルエン投与下に，低量B1の長期投与が行われれば，
表17 アリナミ゙ン $5 \mathrm{mg} 1$ 週間連続経口投与に よる血中 B 1 値（リウマチ患者）

\begin{tabular}{|c|c|c|c|c|c|c|c|}
\hline \multirow{3}{*}{ 例 } & \multirow{3}{*}{ 氏名 } & \multicolumn{6}{|c|}{ 血中 $B_{1}$ 値 $(\mu \mathrm{g} / \mathrm{d} 1)$} \\
\hline & & \multicolumn{3}{|c|}{ 投 与 前 } & \multicolumn{2}{|c|}{1 週 } & \\
\hline & & $\begin{array}{c}\text { 遊離型 } \\
\mathbf{B}_{1}\end{array}$ & 総 $\mathbf{B}_{1}$ & \begin{tabular}{|c|}
$\mid$ 結合型 \\
$\mathbf{B}_{1}$
\end{tabular} & \begin{tabular}{|c|} 
遊離型 \\
$\mathbf{B}_{1}$
\end{tabular} & 総 $B_{1}$ & \begin{tabular}{|c} 
結合型 \\
$\mathbf{B}_{\mathbf{1}}$
\end{tabular} \\
\hline 1 & 明 $\bigcirc$ & 0.3 & 5.9 & 5.6 & 2.9 & 11.2 & 8.3 \\
\hline 2 & 平 $\mathrm{O}$ & 0.6 & 4.5 & 3.9 & 0.7 & 9.2 & 9.0 \\
\hline 3 & 馬 & 0.5 & 4.4 & 3.9 & 0.8 & 7.0 & 6.2 \\
\hline 4 & 中 $\bigcirc$ & 0.8 & 2.8 & 2.0 & 2.5 & 6.1 & 3.6 \\
\hline 5 & 藤 $\bigcirc$ & 0.3 & 3.4 & 3.1 & 0.3 & 6.6 & 6.3 \\
\hline 6 & +0 & 0.8 & 6.1 & 5.3 & 0.9 & 9.9 & 9.0 \\
\hline 7 & 岩○ & 0.9 & 6.8 & 5.9 & 1.7 & 7.6 & 5.9 \\
\hline 8 & 池O & 0.8 & 7.3 & 6.5 & 1.0 & 7.5 & 6.5 \\
\hline 9 & 三0 & 2.2 & 6.5 & 4.3 & 0.5 & 6.0 & 5.5 \\
\hline 10 & 尾 $\bigcirc$ & 1.2 & 2.7 & 1.5 & 0.3 & 7.6 & 7.3 \\
\hline 11 & 横 $\bigcirc$ & 0 & 8.6 & 8.6 & 0.5 & 10.9 & 10.4 \\
\hline 12 & 金O & 0.5 & 4.8 & 4.3 & 0.5 & 6.2 & 5.7 \\
\hline 13 & 景○ & 0 & 3.9 & 3.9 & 1.3 & 5.8 & 4.5 \\
\hline 14 & 国O & 1.0 & 6.2 & 5.2 & 1.0 & 6.4 & 5.4 \\
\hline 15 & 麻 $\bigcirc$ & 0.8 & 6.9 & 6.1 & 0.8 & 8.7 & 7.9 \\
\hline 16 & 尾○ & 0.6 & 5.8 & 5.2 & 1.2 & 6.9 & 5.7 \\
\hline 17 & $\equiv \bigcirc$ & 0 & 2.9 & 2.9 & 1.1 & 4.9 & 3.8 \\
\hline 18 & 藤つ & 2.3 & 5.4 & 3.1 & 2.9 & 6.3 & 3.4 \\
\hline & ( & 0.7 & 5.3 & 4.6 & 1.2 & 7.5 & 6.3 \\
\hline & & & & & $\mid \begin{array}{r}(+) \\
0.3\end{array}$ & $\begin{array}{r}(+) \\
2.2\end{array}$ & $\begin{array}{r}(+) \\
1.7\end{array}$ \\
\hline
\end{tabular}

（註. 副腎皮質ホルモン治療下に於いて）

表18アリナミン $5 \mathrm{mg} 1$ 週間連続経口投与に よる血中 $\mathrm{B}_{1}$ 値（健康者）

\begin{tabular}{|c|c|c|c|c|c|c|c|}
\hline & \multirow{3}{*}{ 氏名 } & \multicolumn{6}{|c|}{ 血中 $B_{1}$ 値 $(\mu \mathrm{g} / \mathrm{dl})$} \\
\hline & & \multicolumn{3}{|c|}{ 投 与 前 } & \multicolumn{2}{|c|}{1 週 } & \\
\hline & & \begin{tabular}{|c} 
避離䅅 \\
$\mathrm{B}_{\mathbf{1}}$
\end{tabular} & 総 $B_{1}$ & $\begin{array}{c}\text { 結合型 } \\
\mathrm{B}_{1}\end{array}$ & \begin{tabular}{|c|} 
遊離型 \\
$\mathbf{B}_{1}$
\end{tabular} & 総 $\mathbf{B}_{1}$ & \begin{tabular}{|c} 
結合型 \\
$\mathbf{B}_{\mathbf{1}}$
\end{tabular} \\
\hline 1 & 栗O & 0.3 & 5.0 & 4.7 & 1.1 & 5.8 & 4.7 \\
\hline 2 & $\equiv 0$ & 1.4 & 5.9 & 4.5 & 0.9 & 7.2 & 6.3 \\
\hline 3 & 児○ & 0.3 & 4.8 & 4.5 & 1.0 & 5.7 & 4.7 \\
\hline 4 & 不 & 0.2 & 5.3 & 5.1 & 1.1 & 7.5 & 6.4 \\
\hline 5 & 平 0 & 2.1 & 3.1 & 1.0 & 5.6 & 6.5 & 1.0 \\
\hline 6 & 高○ & 0.7 & 3.5 & 2.8 & 1.7 & 6.3 & 4.6 \\
\hline \multicolumn{2}{|c|}{ 平均値 } & 0.8 & 4.6 & 3.8 & 1.9 & 6.5 & 4.6 \\
\hline & & the & & & $\begin{array}{c}(+) \\
0.8\end{array}$ & $\begin{array}{l}(+) \\
1.9\end{array}$ & $\begin{array}{c}(+) \\
0.8\end{array}$ \\
\hline
\end{tabular}




\section{第林章 粉括並び考按}

リウマチと B 1 に関しては, 緒言で述べた 如く， Stein, Fletcher 等は $\mathrm{B}_{1}$ 欠乏を報告し， $\mathrm{B}_{1}$ 或は $\mathrm{B}_{1}$ を含む複合体を投与することによりリウマチ症状の好 ． 転をみたと報告し，反対に Freyberg はリウマチに 対しB1は無効であると報告した。齊藤及びその一門 の研究によ机ば、リウマチの原因は $\mathbf{B}_{1}$ 欠乏十 $\mathbf{x}$ であ るとし，B19大量投与が良好な 結果を得たとしてい る, 尙前川28 の钼察によれば,リウマチ発症の誘因 として溶連菌感染が大きな役割を果すと考え, リウマ 千はB 1 久乏十異常刺戟（細菌, 異種蛋白, 患者自体 の異常分解産物等）としている. 又鈴汇 ${ }^{20}$ は は $\mathrm{B}_{1}$ 欠之 により組樴アレルギーが強められた結果, リウマチ様 病変を起すとしている. 又矢野及びその一門による詳 細な臨床的研究の結果, リウマチと $\mathrm{B}_{1}$ との関係につ いて， $\mathbf{B}_{1}$ 摄取不足による久乏ではなく肝機能障害及 ひ内分泌障害に由来する内因性の利用不全であると推 論している.

$\mathrm{B}_{1}$ の生理作用は，ピロ燐酸エステルの形で発揮さ れるが，この形になる為には丵酸 2 分子の結合が必要 であり，この附煒はアデノシン三燐酸（A T P ）から 供給 されると考えられている． 即ち 1939 年 WeilMalherbe ${ }^{80}$ に始まる一連の酵素の研究により， $\mathrm{B}_{1}$ か5A T P の存在のもとに Cocarboxylase の生成が 認められたのであるが，真野は1はA TPの外にアテ ノシン二燐酸 (ADP) の存在のもとにもかかる反応が 行われ，ADPはATPの3の効果を示したと述へて いる.

この Cocarbexylase は情質代謝と密接な関倸を有 し，生体組維内での棓質代謝の中間産物たるピルビン 酸 (焦性フドー酸) は酸化によつて炭酸ガスと水に分 解するか，この機序に関与し，これは Krebs'22 の提 唱せるクエン酸回路(TCAサイクル)を経るものであ る.即ちピルビン酸がこの回路に入る第 1 段は酸化的 脱炭酸であつて, 助醅A (Co-Enzyme A) の存在 によつて、アセチル Co-Enzyme A を生ずる.ここ に生じたアセチル Co-Enzyme A は，縮合醉美の存 在において,オキサル酢酸と反応してクェン酸を生じ， クエン酸回路に入るのである. この時 Co-Enzyme A が活性酢酸基の授受を行い，この反応を触媒する 醉素が, Cocarboxylase を助醉素としている.Cocarboxylase 助䣼絜とする䣼素が作用する基質は, ピルビン酸のみでなく、クェン酸回路の一員であり， クルタミン酸の酸化によつて出来る 酸についても同様の反応が行われている83!。
前述の如く B1から Cocarboxylase を生ずる為に は ATP, ADP を必要とし，この附燐は主として肝

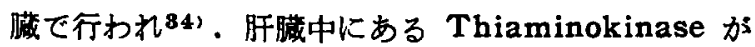
$\mathbf{M g}^{++}, \mathrm{Mn}^{++}$の存在で生合成を行ら,ものである ${ }^{\mathbf{8 6})}$ 。 従つて肝機能障害があれば， B $_{1}$ より Cocarboxylase となる附燐機序に何等かの障碍が怙こり， $\mathbf{B}_{1}$ 活生化 の障害を来たすのであううといわれている.

Carlström862はATPを用いて関節りウマチを治 療し66\%に有効であると報告し，Vogt87)はA T P は 副堅皮質ホルモンの分泌をを促すという.

関節リウマチと肝障害に関しては, Bergstrand, Bersaques, Bérat, Bachert38) 38) の報告があり， いずれも肝障害を認めて居り，矢野40)，児玉(俊)も 関節リウマチの症状の重さに比例して肝機能が冒され るといつている．Fellinger88 は関節リウマチ患者 の肝機能障碍を起し易い原因か，副堅皮質不全に由来 するのであろうと推定し，矢野 ${ }^{80}$ も下垂体副腎皮質 系の機能脱落が肝障害を起すと推定している，更に第 5 章 2 節で述べた如く, 井上, 峰下, 小黒, 高橋等の 報告もある.

又抟血と $B_{1}$ に関して沢田は41) 血中 $\mathrm{B}_{1}$ 値は赤血球 数に左右されるといい，又リウマチ患者の大部分に責 血か認められている事実より， B 1 血中濃度の低下も 考えられるわけである.

以上の報告をもとにして実駼結果を考察するに，第 3 章で述べた如くリウマチ患者の $\mathrm{B}_{1}$ 血中濃度は健康 人に比して明らかに低值を示し，又附煙率の低下が認 められ，Stage, cab. の六進と共に赤沈值が亢進し， これと平行する如く附燐率の低下が見られる.

$B_{1}$ 負荷実耠では井上のいわゆる第型に類似の結 果を得, $\mathbf{B}_{1}$ 利用能の低下の型を示している.

ヌリウマチドックよりの実験結果によれば， $\mathrm{B}_{1}$ 利 用能低下による血中 $\mathbf{B}_{1}$ 值の減少は認められるが，臨 床症状観察の結果より，血中 $\mathbf{B}_{1}$ 值が上界してもリウ マチに対して直接の鎮痛効果は少ない様に思われ（第 $\mathrm{V}$ 章, 第 1 節)， $\mathrm{B}_{1}$ 血中濃度に対して，プドニソロ ン, メドロール等が $\mathrm{B}_{1}$ の尿中排泄をやや减少させ， かつ血中濃度を上年させるが、フタソリジンは逆に血 中泼度を減少させた。而してアリナミン及びATPの 併用は総 $\mathrm{B}_{1}$ 值の高度の上年は見られないにも関わら ず，避離型 $\mathrm{B}_{1}$ が著しく减少し，結合型 $\mathrm{B}_{1}$ の著明な上 界を示した（第 $\mathrm{V}$ 章，第 2 節)。更にこれを臨床検査 と比較した結果，副腎皮質ホルモンと $\mathrm{B}_{1}$ の併用療法 は, 疼痛柽減と其に賛血, 赤沈値, 肝臓機能に有利的 に作用するが、フタソリジンとB、併用では泈痛の軽 
减は見られても，筧血の再現，赤沈及び肝機能障碍の 再穴進が見られ，これと共に血中 $B_{1}$ 値も低下してい た. 又副督皮質ホルモン、ブタソリジンの低量投与の 下に於て，ATP，アリナミンの併用は症状を好転さ せた (第 V章, 第3 節).

各種 $\mathrm{B}_{1}$ 郕の 1 週間連続投与では，総 $\mathrm{B}_{1}$ 值の增加は Cocarboxylase 及びアリナミンがほほ同様で传り， B 1 はややこれらよりおとる．更に結合型 $\mathrm{B}_{1}$ 値の上䄯 は.Cocarboxylase が有効で、アリナミンがこれにつ

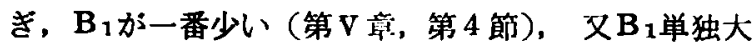
量投与よりも，副堅皮質ホルモン投与下に於て， $\mathbf{B}_{1}$ の長期連続低量投与がリウマチー般症状の改善に役立 つと考えられる（第 $\mathrm{V}$ 章, 第 5 節).

前述の如く $\mathrm{B}_{1}$ 代謝は糖質代謝に重要な役割を演じ ており， B 1 代謝障害は当然焙質代謝に異状を来すも のと考えられ，更にこれは蛋白及び脂肪代謝に迄影響 を及ぼす事が推察されるのである.

リウマチに関し，その真の原因が未だ少，一元論的 には説明し切れない現状において、リウマチドックに 入院せるリウマチ患者について，そのB 1 代謝を中心 に, 臨床実験を行つて以上の如き結果を得たのであ る.

リウマチの治療に当つて，副堅皮質ホルモンによる 治㞠は欠くへからさるものであることは言をまたない か，更に一般諸症状改善の為に，上記副腎皮質ホルモ ンの他， $\mathbf{B}_{1}$ 鼡の長期低量連続投与は有効に作用し， しかも Cocarboxylase 或はアリナミンが他のB 剠 よりも有効であり，更にA T P の併用はその結合型 $\mathrm{B}_{1}$ の增加に特に有効である様に考えられる. 又これと併

文

1) Stein, Hans : Fortschr., 5, 823, 1929.

2) A. A. Fletcher : J.A.M.A., 101, 1264, 1933.

3) Freyberg, A. A. : J.A.M.A., 119, 1165, 1942.

4) Borson, !Harry J. : Ann. Jnt. Med., 14, 1, 1940.

5 ) 齊藤二郎ほか：日本臨床，9，275，1951.

6）近森信男：京府医大誌, 47, 265, 昭25.

7 ）佐山周子：京府医大誌, 55, 619, 昭29.

8）矢野良一・伊藤昭華：アリナミン文献集，II, 4, 昭29.

9）伊藤昭華：温研報， 8，1, 昭31,

10）八木国夫・藤原元典編：最新ビタミン定量法, 医 菡薬出版，1, 昭29.

11）井上硬・桂英輔：ビタミン学, 金原出版, 351 ,
行して肝䐵保護療法も，血中 $\mathrm{B}_{1}$ 值上年に，ひいては リウマチ症状改善に役立つものであると推論したい.

\section{第叫章 結 論}

1)リウマチ患者の血中 $\mathrm{B}_{1}$ 量は，健康者に比して低 值を示し, 特に結合型B 1 が少く, 附哖作用の低下が 推定される。 又 Stage, Class の進行と共に赤沈及び 肝機能障碍の亢進が見られ，それに平行する如く附燐 率の低下が見られた。

2) リウマチ患者の $\mathrm{B}_{1}$ 欠之は，利用能の低下による 血中 $\mathrm{B}_{1}$ 值の减少と考えられる。

3）リウマチドックにて臨床症状観察の結果より，大

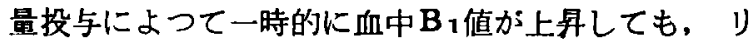
ウマチに対して直接の鎮痛効果は少ない樣に思われ， 大量投与よりもむしろ副腎皮質ホルモン治療と共に長 期間に亘る $\mathbf{B}_{1}$ の低量連続投与が望ましい。

4) B 代謝改善には, アリナミン, Cocarboxylase

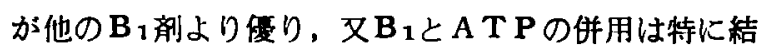
合型 $\mathrm{B}_{1}$ 値上昇に有効であつた．向これと併行して肝

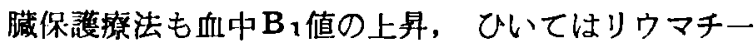
般症状の改善に役立つものと推論したい。

稿在終るに臨み，䅂始御懇䉆なる御指導と御校閲を 睗わつた恩師児玉俊夫教授に柬心より謝意を捀げま す.更に本研究に専門的な御教授を仰いだ岡山大学生 化学教室水原舜爾教授に謝意を呈すると共に, 種々実 験上の御指導をいただいた当教室寺岡集師に感謝の意 を表します。文実験上の援助をいただいた技術員黑田 姣に対し感謝いたします。

\section{献}

昭31.

12）ビタミン B研究特別委具会：ビタミン，1，246， 昭23.

13) Fills : Bioch. J., 33, 1966, 1939.

14) Robinson, Melnick, Field : J. Clin. Invest., 19, 399, 1940.

15）小川：熦在性ビタミン久乏症とその発見方法, 第 一出版。18，炤25.

16) Magyar : Klin' Wschr., 20, 425, 1941.

17) Westenbrink, Goudsmit : Nature, 139, 1108, 1937.

18）岩松策・弘中良英：屋応医学，24，679, 昭19.

19）井.上硬：第14回日本医学会総会特別講演笨，431, 昭30。 
20）児玉俊夫ほか：臨床の日本，3，634，昭32。

21）井上硬ほか：ビタミン，7，990，昭29.

22）井上硬ほか：ビタミン，8，184, 昭30。

23) 井上硬ほか：ビタミン，6，845, 昭28.

24）峰下鉄雄ほか：ビタミン，7，478, 昭29。

25）小黒八七郎：内分泌, 3, 177, 昭32.

26）高橋忠雄：日本医師会雑誌, 29, 618, 昭28.

27) 小林博介: ビタミン, 8,480 , 昭30.

28) 前川保郎：京府医大誌, 57, 691, 昭30.

29）鈴江愪：リウマチ新説, 南山堂, 114, 1951.

30) Weil-Malherbe, H.: Biochem. J., 33, 1997, 1939.

31）真野嘉長・田中亮：醉素化学シンポジウム講演 集, 1, 128, 1956.

32) Krebs, H. A. : Biochem. J., 34, 775, 1940.
33）島萺順雄 : ビタミン学, 金原出版, 333, 昭31.

34) Ochoa, S. : Biochem. J., 33, 1262, 1939 ; Nature, 141, 831, 1938.

35）八木国夫 : ビタミン，8，399, 昭30.

36) Carlström : Act. Med. Scand., 110, 230, 1942.

37) Vogt, Marthe : J. Phys., 108, 45, 1949.

38) K. Fellinger u. J. Schmidt : Klinik und Therapie des chronischen Gelenkrheumatismus, 238, 1954.

39) 矢野良一ほか：臨床リウマチ学, 医学書院, 103, 1958.

40）矢野良一：実験治療，281，174, 昭30.

41）沢田藤一郎：臨床と研究 .31, 923, 昭29.

42) Steinbrocker, O. et al : J.A.M.A., 140, 659, 1946. 


\title{
Clinical Investigation on Thiamine Metabolism in Rheumatoid Arthritis
}

\author{
By \\ Hiroshi KODAMA, M. D. \\ Department of Orthopedic Surgery, Okayama University Medical School \\ (Director : Prof. T. Kodama)
}

The clinical investigation regarding to vitamin $B_{1}$ metabolism was performed on rheumatoid arthritis during one month of admission, during which period the various antirheumatic agents were given to these patients.

1) The total thiamine levels of blood in rheumatoid arthritis was low compared with normal healthy people, specifically low in ester type suggesting the decrease of phosphorylation. There was also present the advancements of erythrocyte sedimentation rate and disturbed function of liver with advance of "stage" and "class" of this disease. The decrease of rate of phosphorylation was seemed to be parallel to them.

2) It is able to consider that the vitamin $B_{1}$ deficient of rheumatoid arthritis is due to the decrease of vitamin $B_{1}$ level in blood resulted from the lower efficiency of vitamin utilization.

3) It is concluded from the observations of clinical symptoms at the rheumatoid arthritis that as the temporary elevation of vitamin $B_{1}$ level in blood by administration of large dosage of vitamin $B_{1}$ appears to be insufficient in analgetic activity for rheumatoid arthritis, so it seems better in the treatment by corticoids with small dosage of vitamin $B_{1}$ administration for long period rather than by large dosage for short period.

4) For the improvement of vitamin $B_{1}$ metabolism, thiamine propyl disulfide and cocarboxylase are more effective than the other, and the combind administration of vitamin $B_{1}$ with ATP was effective, specifically for the elevation of ester type of vitamin $B_{1}$. It will be concluded that the protecting treatment of liver function is also useful not only for elevation of the value of vitamin $B_{1}$ in blood but also for the improvement of general symptoms of rheumatoid arthritis. 